Portland State University

PDXScholar

5-7-1997

\title{
Japanese Intelligibility and Comprehensibility Assessments of Different English Accents
}

David Michael Levin

Portland State University

Follow this and additional works at: https://pdxscholar.library.pdx.edu/open_access_etds

Part of the Bilingual, Multilingual, and Multicultural Education Commons Let us know how access to this document benefits you.

\section{Recommended Citation}

Levin, David Michael, "Japanese Intelligibility and Comprehensibility Assessments of Different English Accents" (1997). Dissertations and Theses. Paper 5312.

https://doi.org/10.15760/etd.7185

This Thesis is brought to you for free and open access. It has been accepted for inclusion in Dissertations and Theses by an authorized administrator of PDXScholar. Please contact us if we can make this document more accessible: pdxscholar@pdx.edu. 


\section{THESIS APPROVAL}

The abstract and thesis of David Michael Levin for the Master of Arts in

TESOL were presented May 7, 1997, and accepted by the thesis committee and the department.

COMMITTEE APPROVALS:

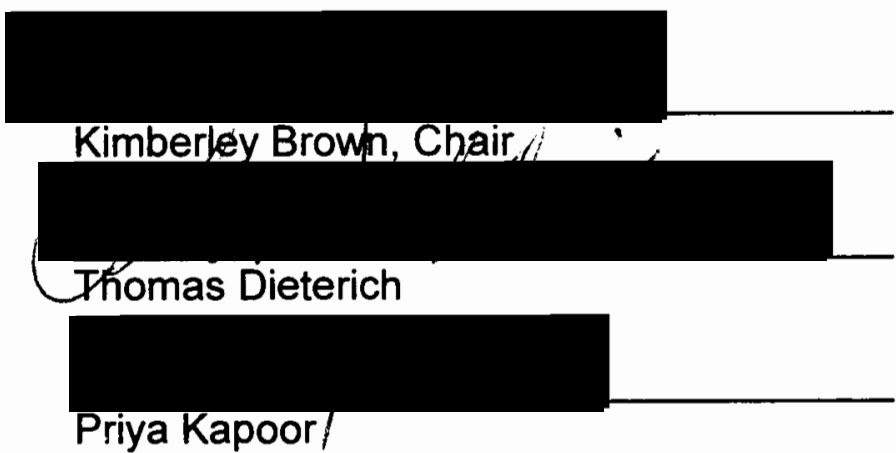

Representative of the Office of Graduate Studies

DEPARTMENT APPROVAL:

Marjorie' Terdal, Chair

Department of Applied Linguistics

ACCEPTED FOR PORTLAND STATE UNIVERSITY BY THE LIBRARY

by on

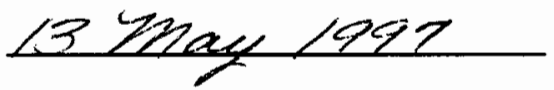




\section{ABSTRACT}

An abstract of the thesis of David Michael Levin for the Master of Arts in TESOL presented May 7, 1997.

Title: Japanese Intelligibility and Comprehensibility Assessments of Different English Accents

As the result of historical events and the adaptive nature of the language itself, English is generally accepted today as the world's international language. While various countries have adapted the English language to serve their own specific needs, the question of whether or not the changes made to English in these countries, for example phonological, will still enable the language to be intelligible in the international arena. If English is to be the de facto world language, then international intelligibility should be an important goal.

For this research, 211 Japanese university students were asked to assess the intelligibility and comprehensibility of the English spoken by educated speakers from Japan, Taiwan, India and the United States. These countries were chosen based on Kachru's Inner, Outer, and Expanding Circles of English. The Inner Circle includes the traditional "native" English 
speaking countries such as the United States and Great Britain. The Outer Circle includes countries such as India or Malaysia where English is used for intranational purposes. The Expanding Circle refers to those countries such as Japan or Egypt where English use is widespread yet serves few intranational purposes. In addition for this research, intelligibility is defined specifically as word/utterance recognition, and comprehensibility as word/utterance meaning.

Results showed that these Japanese university students assessed the Japanese speaker to be the most intelligible, the Taiwanese and American speaker were found to be statistically the same, and the Indian speaker was judged to be the least intelligible. For the comprehensibility element, the Japanese speaker was assessed as the most comprehensible followed by the Taiwanese, Indian and American speakers.

If international intelligibility is looked at in terms of a range of what accents will be deemed acceptable for multinational communication, then Japanese university students appear to only understand part of this range. If Japanese EFL students wish to communicate more widely within the English speaking world, then steps are needed to expand the range of internationally intelligible accents that will be understood. Activities such as pronunciation practice will help Japanese EFL students comprehend the intonation patterns found among Inner Circle speakers which includes American English speakers. 
JAPANESE INTELLIGIBILITY AND COMPREHENSIBILITY ASSESSMENTS

\section{OF DIFFERENT ENGLISH ACCENTS}

by

DAVID MICHAEL LEVIN

A thesis submitted in partial fulfillment of the requirements for the degree of

MASTER OF ARTS

in

TESOL

Portland State University

1997 


\section{ACKNOWLEDGMENTS}

First of all, I would like to thank my advisor Kimberley Brown for all of her time, advice and patience in helping me complete this research. In addition, I would like to thank my committee members Thomas Dieterich and Priya Kapoor for their participation and comments. I am particularly grateful to Jim Hawrylak for the enormous amount of help he gave me in carrying out the study in Japan. I would also like to thank Priya Kapoor, Eriko Maeda, Yuki Dooley, Jui-Fang Chen, and Cheryl Fischer for their help in the development of the materials used in the research. Finally, I would like to thank the students who participated in this project. 


\section{TABLE OF CONTENTS}

PAGE

ACKNOWLEDGEMENTS.......................................................... ii

LIST OF TABLES.................................................................. vi

LIST OF FIGURES..................................................................... viii

\section{CHAPTER}

I INTRODUCTION................................................................. 1

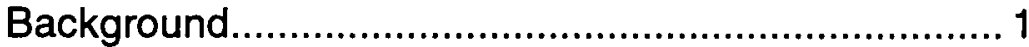

Statement of Research Hypotheses........................... 4

II REVIEW OF THE LITERATURE...................................... 6

English as an international language and World Englishes.

English as an International Language World Englishes

English in Japan

English Loanwords

Intelligibility

Intelligibility

Conclusion 
III METHODOLOGY.................................................... 25

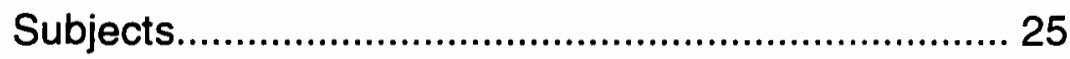

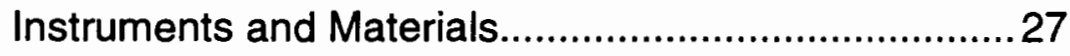

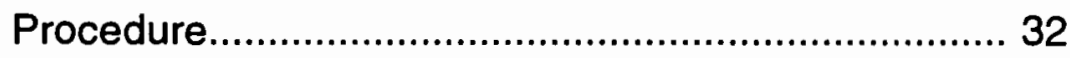

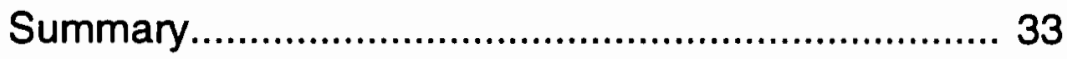

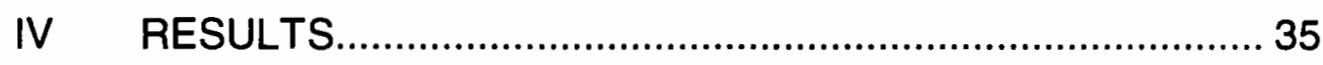

Hypotheses........................................................ 35

ANOVA Analysis..................................................... 37

Intelligibility

Comprehensibility

Correlation Analysis.................................................... 43

Intelligibility

Comprehensibility

Other Assessments............................................... 52

Question 3

Question 4

Question 5

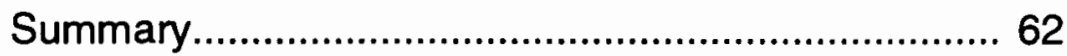

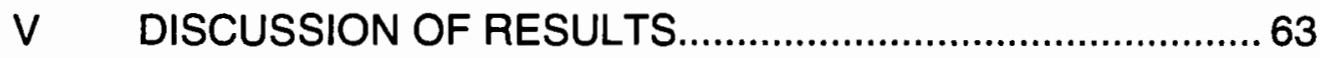

Discussion of Findings.............................................. 63

Intelligibility and Comprehensibility Results

Correlation Results

Other Results from Subjective Evaluation

Questionnaire 


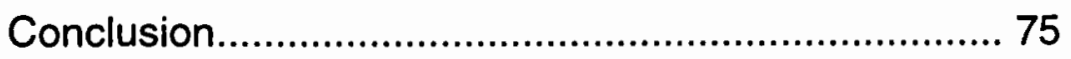

Implications for World Englishes and TESOL.............. 76

Limitations and Methodological Problems................. 79

Suggestions for Further Research............................. 80

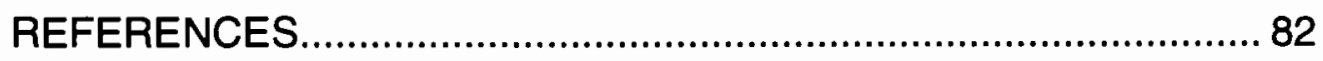

APPENDICES

A PASSAGES AND CLOZE TESTS............................ 85

B SUBJECTIVE AND PERSONAL DATA

QUESTIONNAIRES....................................96

C TRANSLATIONS AND BACK-TRANSLATIONS......... 100 


\section{LIST OF TABLES}

TABLE

PAGE

I PERSONAL DATA SUMMARY OF STUDENTS.................... 27

II SUMMARY OF PASSAGE STATISTICS............................ 29

III ANOVA FOR CLOZE TEST SCORES............................... 39

IV BONFERRONI TEST FOR CLOZE TEST SCORES.............. 40

V ANOVA FOR PASSAGE TEST SCORES.......................... 42

VI BONFERRONI TEST FOR PASSAGE TEST SCORES....... 43

VII SPEARMAN'S CORRELATION COEFFICIENT FOR JAPANESE SPEAKER ................................................. 47

VIII SPEARMAN'S CORRELATION COEFFICIENT FOR TAIWANESE SPEAKER ............................................... 47

IX SPEARMAN'S CORRELATION COEFFICIENT FOR INDIAN

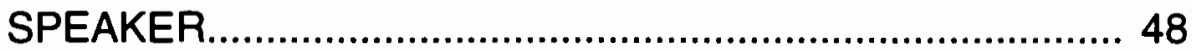

$X$ SPEARMAN'S CORRELATION COEFFICIENT FOR AMERICAN SPEAKER ................................................ 49

XI SPEARMAN'S CORRELATION COEFFICIENT FOR JAPANESE SPEAKER ................................................. 50

XII SPEARMAN'S CORRELATION COEFFICIENT FOR TAIWANESE SPEAKER ................................................. 50

XIII SPEARMAN'S CORRELATION COEFFICIENT FOR INDIAN SPEAKER.

XIV SPEARMAN'S CORRELATION COEFFICIENT FOR AMERICAN SPEAKER. 
XV ANSWERS TO QUESTION 3 BASED ON JAPANESE SPEAKER 53

XVI ANSWERS TO QUESTION 3 BASED ON TAIWANESE SPEAKER. 54

XII ANSWERS TO QUESTION 3 BASED ON INDIAN SPEAKER. 55

XIII ANSWERS TO QUESTION 3 BASED ON AMERICAN SPEAKER 56

XIX PERCENTAGES GIVEN FOR QUESTION 5. 61 
LIST OF FIGURES

FIGURE

PAGE

1. SOME DISTINCTIVE FEATURES OF ESOL vs. EIIL............. 10

2. COMPARISON OF MEANS FOR CLOZE TEST SCORES....38

3. COMPARISON OF MEANS FOR PASSAGE TEST SCORES.

4. NATIONALITY GUESSES MADE FOR JAPANESE

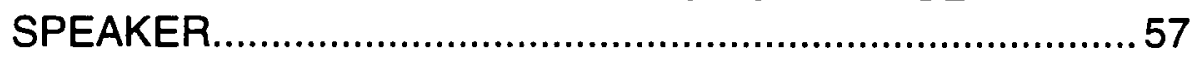

5. NATIONALITY GUESSES MADE FOR TAIWANESE

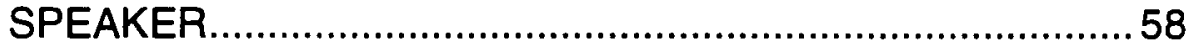

6. NATIONALITY GUESSES MADE FOR INDIAN SPEAKER... 59

7. NATIONALITY GUESSES MADE FOR AMERICAN SPEAKER. 60 


\section{CHAPTER I}

\section{INTRODUCTION}

\section{BACKGROUND}

Six years ago, while applying for a teaching position within a junior high school system in Japan, it struck me as curious the request that a photo be included with my application. It was later explained to me that the purpose was to separate out individuals on the basis of appearance, appearance meaning, does the individual look gaijin enough, or translated, "Western" or "White" in this case. The assumption is that only White, 'Native' English speaking teachers possess the innate ability to teach English. This is regardless of the teaching qualifications these individuals possess although the qualifications for the more desirable jobs have tightened due to the current glut of English teachers in Japan today.

Two years of observation while living in Japan, as well as anecdotal evidence from English teaching peers, has led me to conclude that there is indeed a prejudicial element to the 'White' qualification, (non-white English teachers are in the clear minority in Japan). Moreover, these same observations have led me to believe that there appears to be a general 
assumption among Japanese administrators, and Japanese English students, that the native varieties of English are the only target models for English ability. From personal experience and anecdotal evidence alone, this assumption and need for the native variety as the sole target is unfounded. The needs of most Japanese EFL learners in their current academic structure could easily be met by any qualified English teacher who is a speaker of any variety of English; native or non-native. In Chapter two, I will look at Japan's historical and current involvement with the English language.

Furthermore, the growing body of research in the field of World Englishes (c.f., Kachru (1995), Nelson (1988) Smith (1985)) dictates the need for an internationally intelligible English as a realistic and preferred target for many learners so wishing to communicate in English globally, as opposed to only a native variety of English.

I often found it ironic teaching American English to Japanese businesspeople, (mainly men), who were preparing to travel to, or live and work overseas in countries such as Indonesia, Switzerland, Thailand, and Pakistan. Wouldn't an English teacher from these countries be more insightful and helpful in preparing these businesspeople to understand the particular variety of English spoken in these countries?

This and other questions regarding World Englishes are addressed by several researchers in the field. In particular, Kachru, one of the World Englishes originators and promoters, has developed a paradigm from which 
the dichotomy of the native/non-native English speaking world is transcended. Kachru's view describes the English speaking world in terms of three circles, (to be discussed further in chapter two): Inner, Outer and Expanding. The Inner Circle includes countries like the U. S. or the U.K.; the Outer Circle includes countries like India or Malaysia; and, the Expanding Circle includes countries like Japan or Germany. From this view, different varieties of English can begin to be recognized as unique and legitimate in their own right without comparison to some historically imposed model.

Interestingly, within the language school in which I taught in Japan, the phonological differences between other Inner Circle (naive) speaking teachers and myself often was as great as the accent difference between the English speaking Japanese students and these teachers. This means that sole reliance on an Inner Circle variety does not necessarily ensure unanimity in phonological character. It may be that a strong Australian or Southern U.S. accent, while Inner Circle varieties of English, would be far less intelligible than an educated Outer Circle (non-native) Indian variety.

However, there was a tendency for all of the teachers I worked with to speak a more generic, internationally intelligible dialect of English as our length of stay increased in Japan. This might indicate that this 'international English dialect' is a form of English derived from the accommodation necessary for international communication among the several varieties of English in the world. 
As a researcher, I wish to investigate the differences in phonology, or accents that exist among a number of educated varieties of English. In particular, I am interested in how a specific group of English learners assess the intelligibility and comprehensibility, (to be defined specifically in chapter two), of speakers of four different varieties of English. The specific group of learners under investigation will be low level Japanese EFL university students similar to the ones I expect to be teaching.

\section{STATEMENT OF RESEARCH HYPOTHESES}

1. Phonological differences, 'accents', in educated speakers of English from Inner Circle, Outer Circle, and Expanding Circle countries as defined by Kachru (1985), (specifically the United States, India, Taiwan and Japan), affect the intelligibility assessments of these speakers made by beginning Japanese EFL university students.

2. Phonological differences, 'accents', in educated speakers of English from Inner Circle, Outer Circle, and Expanding Circle countries as defined by Kachru (1985), (specifically the United States, India, and Japan), affect the comprehensibility assessments of these speakers made by beginning Japanese EFL university students.

3. Familiarity with any one 'accent' by the above students will influence their intelligibility and comprehensibility assessments. Thus, due to the 
contact that these Japanese listeners have had with these accents, it is believed that they will find the Japanese speaker most understandable followed by the U.S., Taiwan, and India.

4. There is a positive relationship between student assessment of speaker intelligibility and comprehensibility, and student achievement on comprehension and intelligibility tests based on the taped material. I expect that the differences in Inner, Outer, and Expanding Circle countries' 'accents', will affect the intelligibility and comprehensibility assessments made by the subjects. This is due to the research carried out so far that indicates that familiarity with an one accent leads to greater understanding. From personal experience, in this study I predict that the subjects are most familiar with Japanese English followed by American, Taiwanese and Indian English; thus, this order is found in hypothesis 3 . It is hoped that the large number of subjects involved will give the results credibility. By carrying out this research, I not only wish to identify the relationships that these different varieties have with the Japanese EFL learners, but I also wish to contribute to the growing body of research in the field of World Englishes. 


\section{CHAPTER II}

\section{REVIEW OF THE LITERATURE}

As many of us in the TESOL program will set out upon all parts of the world to teach the English language, it is essential that I reflect on this endeavor with regards to the status of the English language in the world today. Several issues naturally arise in our quest to bring English to those who, for one reason or another, need the language for some specific purpose. First, there are issues related to English and its role internationally and the incorporation of the recognition of World Englishes. Second, considering the fact that I will initially be teaching English in Japan, the issues related to this country's situation vis-à-vis English is of particular interest. Additionally, there are issues concerning the intelligibility of the variety of English I speak compared to the intelligibility of the other varieties of English in the world.

To follow, is an investigation into these and other issues pertinent to my research. In particular, I will look at English and its role internationally as well as the paradigm of World Englishes. In addition, I will summarize the history of English in Japan and the present day situation of English including the use of English loanwords. Finally, the concerns regarding intelligibility which are central to the research to be conducted will be investigated as well. 
ENGLISH AS AN INTERNATIONAL LANGUAGE AND WORLD ENGLISHES

\section{English as an international language}

English and its many varieties is spoken by an enormous number of individuals on this planet. Based on Crystal's (1985) statistics that claim that there are an estimated one to two billion users of English in the world, Strevens (1992) settles on a mid-point figure of 1.5 billion users. These users of English range from those who use it everyday as a mother tongue or additional language to those who use it on a limited basis.

Interestingly, the users of English who traditionally call themselves 'native' speakers (NS) are finding that they are increasingly in the minority of English users. "The figures tell us that while English is used by more people than any other language on Earth, its mother-tongue speakers make up only a quarter or a fifth of the total" (Strevens 1992:28).

In addition, Strevens also guesses that around a billion of his working number of 1.5 billion English users have 'learned or picked up' English in the past twenty years. It is this rate of change that has and will continue to have major implications for TESOL instructors going out into this world. As I along with others become English teachers, we are immediately confronted by a number of acronyms: EFL (English as a foreign language), ESL (English as a second language), ELT (English language teaching), EIIL (English as an intranational/international language), EIL (English as an international 
language), ESP (English for specific purposes), and (T)ESOL ((teaching) English for/to speakers of other languages), which usually is a cover term for both EFL and ESL.

An explosion in the variety of these terms reflects the recognition over the past years that the learners of English are vast and varied, and represent different needs. As Strevens (1992:41) states,

The process of gradual sophistication has brought ESL/EFL a long way in barely forty years. From 'teaching English' (undifferentiated as to the learners, and chiefly based on literature) to 'English language teaching' (witness the title of one of the oldest professional publications in the field: (English Language Teaching Journal) to the distinction, first made in British ELT, between EFL and ESL (ESL in British Commonwealth countries, EFL elsewhere), to TESOL (uniting, especially in America, teachers of all varying groups of learners), adding ESP (English for specific purposes) in recognition of the emergence of non-ethnocentric uses of English, and now incorporating EIL (English for international purposes)-the trend is toward ever more subtle differentiations of the learners, their purposes, their speech communities.

Moreover, Smith (1983:15) conveniently summarizes the differences he sees represented in a chart (see figure 1). Smith reminds us with these 
differentiations that the teaching of English takes on a new dimension when the background and needs of the learners are taken into account. 
SOME DISTINCTIVE FEATURES OF ESOL vs. EIIL

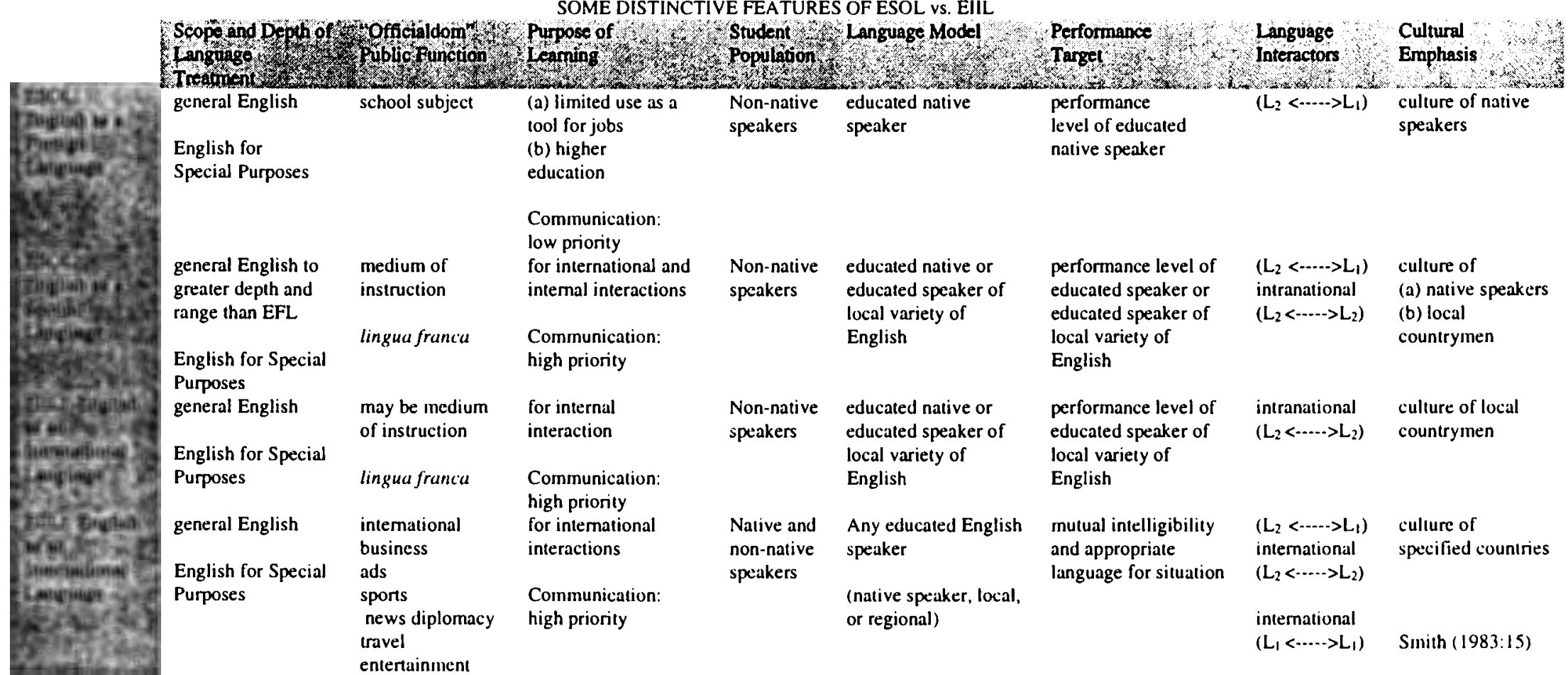




\section{World Englishes}

If the traditional 'native' speakers are now in the minority of a great sea of English users, and the way we use English in America differs to varying degrees from its uses in other countries where it serves some purpose, then it is useful to get some kind of picture of what this 'sea' looks like.

Kachru's (1985) countries that use English are divided up into three concentric circles, an Inner Circle, Outer Circle, and Expanding Circle. The Inner Circle describes that group of countries which is traditionally thought of as the 'Native' speaking countries: the United States, Canada, Great Britain, Ireland, Australia, and New Zealand. Kachru (96:138) terms these "normproducing" countries. The Outer Circle includes countries such as India, Pakistan, Malaysia, Kenya and others where English is used for intranational purposes, and was introduced as a colonial language. Kachru terms these "norm-developing" countries. The final, the Expanding Circle, refers to those countries such as Japan, Egypt, and Indonesia, where English use is widespread, yet serves few intranational purposes. Kachru terms these "norm-dependent" countries. Kachru (1992) also refers to these as performance varieties.

In addition, Englishes used in the Outer Circle countries, while sharing common aspects with Inner Circle English, are stable varieties that have their own pragmatic, lexical, morphosyntactic, and phonological innovations which 
serve the users' unique situations. Kachru (1992:55) describes these Institutionalized varieties further:

It is the institutional varieties which have some ontological status. The main characteristics of such varieties are that (a) they have an extended range of uses in the sociolinguistic context of a nation; (b) they have an extended register and style range; (c) a process of nativization of the registers and styles has taken place; (d) a body of nativized English literature has developed which has formal and contextual characteristics which mark it localized.

Kachru (1990) also brings up the notion of 'cline of bilingualism' when referring to nativized varieties. This refers to the level of English being spoken. For instance, discourse among university professors would generally involve English toward the educated end of this cline; at the other end one might find a pidgin or 'bazaar' type of English. It is important to note that the level on the cline that one is speaking depends on variables such as ability and interlocutors. Closely associated with this cline is Platt and Weber's (1979) lectal range; either acrolect, mesolect, or basilect, (acrolect being the educated variety). This cline would also be applicable to the ways English is used in Inner Circle countries as well. In fact, there may be as much diversity in the way English in used in the United States as there is in India. In terms of English being an international lingua franca, the English represented at the 
high end of Kachru's cline (acrolect) of the many different English varieties should produce a stable standard for international communication.

Nelson (1992) nicely gives his vision to the idea of World Englishes; he states:

If the expanding use of English worldwide continues, we will be brought more and more to recognize English as a world language. This is not to say that one will be free to say whatever one likes and call it 'English.' Rather, the community of speakers will by sheer numbers and geographical distribution require active accommodation from all participants to retain a high degree of intelligibility across varieties (pp. 336-337).

\section{ENGLISH IN JAPAN}

Considering the fact that the subjects participating in this study are Japanese, I feel that it useful to look at the history of English in Japan. It is important to understand what the language policies have been and what changes they have undergone in reaching the state that they are in today. It is equally important to investigate the current situation that the English language finds itself in Japan and how it may influence those studying English such as the subjects participating in this research. 
Ike (1995) provides a useful summary of English in Japan. In recorded history, Japan first had contact with the English language when William Adams, an English sailor who had washed up on a beach in Kyushu (Japan's main southern island), and held an awkward conversation sometime later with the inquisitive Shogun Tokugawa. The conversation, held sometime in 1600, involved the use of two interpreters. From that time until 1858 the Japanese contact with English was intermittent.

In 1858 with the noted arrival of Commodore Perry, a subsequent 'opening up' of Japan took place. The year 1868 saw the beginning of trade relations between the U.S. and Japan. This was also the opening for American Christian missionaries and, "In fact it was due to American missionaries that American rather than British English became the standard taught in Japan" (Ike 1995:4).

English education along with trade took off after the opening up to the west. Studying English was first embraced as there was a push to Westernize under the Meiji Restoration. Emphasis was at first placed on literacy competence; and, the desire to read books to gain insights into Western thought and culture, combined with the few opportunities to actually speak English, led to the popularity of the grammar-translation method. Changes in this approach were first led by an individual named Palmer, who advocated an "aural/oral" approach (Ike 1995:8). 
As expected, English and Western influence suffered in the years from 1924 leading up to and through World War II. However, after 1945, learning English became popular again and widely embraced. A method developed by Fries, an oral approach, became the accepted method for the 1950's. As a result, the researcher states, "Fulbright scholarships supported many teachers annually for study abroad, and scholars from The English Language Institute of the University of Michigan, such as Fries and Lado, had great influence on the enthusiasm for the aural-oral approaches"(Ike 1995:9).

Presently, Japanese English education is promoting a more communicative approach. Present demands of the international climate in which Japan finds itself among the world's leaders (business, tourism, etc.) are creating a strong demand for communication in English.

These current changes reflect the situation in English teaching in Japan in the 1980's and 90's. An eleven-year study by the Committee for Research on English Language Teaching in the Japanese School System revealed important results to back changes in the system. The survey, conducted by Koike et. al. (1990), consisted of questionnaires sent out to,

TEFL administrators, college and university English teachers, junior and senior high-school English teachers, primary-school English teachers, teachers with experience in educating Japanese students overseas, college and university students, and college graduates at large. The survey concludes 
that TEFL within the Japanese educational system is not very effective. For example, 62.6 percent of junior high-school teachers, 58.0 percent of senior high, 80.2 percent of returnee teachers from Japanese schools overseas, and 74.9 percent of college graduates evaluated their English instruction in Japan negatively. Of the college graduates, 74.5 percent felt that they were weak in listening comprehension, 74.5 percent of them felt weak in speaking, and yet 54.3 percent said that they would need English for their business careers. Most of the college graduates (78.3 percent) felt that the main objective for TEFL at the college level should be communication and that much stronger emphasis should be given at the high-school level (Koike \& Tanaka 1995:19).

The conclusions of The AD Hoc Committee for Educational Reform were similar to those of the survey. This committee determined that English instruction in Japan was lacking. In fact, it made four very influential proposals for future English education in Japan. In light of these proposals, the Ministry of Education held a conference in 1987 to decide the future of secondary education.

International communication was the goal which drove the reforms for English education. Among the reforms for senior high-school English classes were the addition of courses called Aural Oral Communications A, B, and C. 
These courses were aimed at improving listening comprehension, speaking, and international understanding. The latter led to the now famous Japan Exchange and Teaching Program (JET). The program, which later included French and German teachers, brought in several Inner Circle English teachers to team-teach in schools throughout Japan.

The researchers conclude that while change is taking place in Japan's educational policies, especially with regard to English, historical factors dictate that the transition to more effective techniques will take some time. However, the impact of English is not only relegated to the status of a foreign language. English loanwords are also an important issue when discussing the use of English in Japan.

\section{English Loanwords}

Several authors (Tanaka 1995, Hayashi \& Hayashi 1995, Kay 1995, Stanlaw 1992, Morrow 1987), have discussed in depth the unique way in which the Japanese have adopted English into the Japanese language itself. In fact, Morrow (1987) that loanwords, "the principle manifestation of the use of English in Japan" (p.61). Kay (1995) elaborates on how English loanwords change as they embed themselves in the Japanese language, or how they adapt to the new cultural and linguistic context. "English words taken into Japanese show orthographical, phonological, structural or semantic integration into the native linguistic system" (p. 68). Furthermore, Hayashi and Hayashi (1995) add that, "In Japan, English loanwords are pervasively used 
regardless of domains, registers, and socio-economic groups. In Japanese discourse, English loanwords are 'embedded' in the Japanese 'matrix' sentences and are assimilated to Japanese phonology, morphology, and syntax in systematic manners" (p.55). Furthermore, the authors elaborate that English loanwords in Japan can represent an example of code-mixing, lexical and cultural borrowing. For example, these loanwords are used intrasententially; the words often do not have Japanese equivalents, and the words are used to express special meanings. (Hayashi \& Hayashi 1995)

Given the nature of Japanese borrowing and incorporation of an increasingly huge number of English loanwords, one might wonder how this interferes with the ability of Japanese to communicate in English as a foreign language. Of particular concern is the reliance on the Japanese system of English pronunciation rather than an internationally intelligible system. Intelligibility

It is useful to begin with an article by Smith and Nelson (1985), in which the researchers summarize research in international intelligibility up to that date. One of their main arguments focuses on the need for researchers in this field to keep separate and distinct three often muddled terms: intelligibility, comprehensibility and interpretability.

The authors state that the following meanings be assigned to each word:

(1) intelligibility: word/utterance recognition, 
(2) comprehensibility: word/utterance meaning (locutionary force),

(3) interpretability: meaning behind word/utterance (illocutionary force) (p. 334).

While I do believe that the term intelligibility, as in international intelligibility, is sufficient when using it in a general sense of 'understanding', I agree with the authors in distinguishing these terms as particular nomenclature for specific research in the area. In this study, I follow this described use of terms.

Before this study, Smith and Bisazza (1982) carried out research concerning the relative comprehensibility of different varieties of English. One of the conclusions was that the traditional 'native' speakers of English should not be the only ones to judge the comprehensibility of other speakers of English. Furthermore, they state that, "native English speakers should be judged for comprehensibility by nonnative speakers too" (p. 259).

In this study, 207 subjects from seven different countries listened to three separate varieties of English, one American, an Indian, and a Japanese. The speakers of these three varieties read different forms of the Michigan Test of Aural Comprehension (MTAC), after which the subjects answered the provided objective questions for the test. In addition, personal data questions and a question asking the subjects to guess the nationality of the speakers were added among other subjective questions.

The researchers concluded that the findings showed: 
1. subjective responses were good indicators of the more objective test results.

2. the nationality of the speaker was difficult to determine from a tape recording of the voice.

3. the greater the active exposure to English in and out of the classroom, the greater the comprehension of English (p.269).

The results also showed that the American speaker was the most easily understood, followed by the Indian and then the Japanese speaker. This seems to reflect the degree of exposure to each variety as determined from the personal data questions.

In fact, the active exposure to certain varieties of English, the researchers ultimately conclude, determines comprehensibility of the variety. It is not enough for English students to just comprehend an Inner Circle variety. Exposure to other varieties is essential if international intelligibility in English is to take place. The authors state, "The assumption that nonnative students of English will be able to comprehend fluent nonnative speakers if they understand native speakers is clearly not correct" (p.269).

Finally, Smith and Rafiqzad (1979), in Smith's earliest investigation into the area of international intelligibility, conducted an ambitious study involving 1,386 subjects from eleven different countries in Asia. The researchers set out to compare the degree of intelligibility between varieties of English. 
At first I found the findings somewhat surprising because the American variety was found to be one of the least intelligible. This was later explained by the fact that the researchers made no attempt to control the level of difficulty in the recorded passages. Not surprisingly, the researchers found a high correlation between intelligibility and level of difficulty.

Interestingly, the researchers did find, "a high level of consistency among the listeners as to the degree of intelligibility"(p.380). The rank ordering of speakers' intelligibility was similar across the eleven countries. The researchers also found that only four out of the seven countries could distinguish their respective countries variety with $70 \%$ accuracy or better.

Smith and Rafiqzad conclude that, "native speaker phonology doesn't appear to be more intelligible than nonnative phonology" (p.380). This could indicate that simply being an Inner Circle variety of English does not necessarily give that variety a competitive edge. It may be that speakers from the Inner Circle will have to make adjustments in speech to accommodate particular listeners under certain circumstances.

Slightly contrary to these results, Chiba, Matsuura \& Yamamoto (1995) conducted a study that has similarities to that which was conducted in my own research. In their study, the researchers played recordings of nine male English speakers from six different countries to 169 Japanese university students from two different universities. Three of the speakers were from Japan, two represented the U.S., one each from the U.K., Hong Kong, Sri 
Lanka, and Malaysia (interestingly, Kachru's three circles are represented though not overtly stated). The subjects were then asked to complete two sets of questionnaires. One questionnaire asked the subjects to give their impressions of the speakers, and the other questionnaire dealt with the subjects' ideas about foreign languages and language learning.

Results of this research showed that, "the subjects' familiarity with native accents leads to a favorable view of native-speaker accent" (p.84). Secondly, weak positive correlation showed that instrumental motivation may affect attitudes toward non-native varieties. In particular, the subjects who valued communicability had fewer negative attitudes toward non-native accents. Finally, the results showed that an endorsement of nativism led to fewer negative attitudes towards non-native accents (p. 84). This final conclusion was determined by the answers on the instrument relating to the appropriateness of non-native varieties.

The researchers conclude that the notion and existence of world Englishes should be advocated in Japan, but that a strong rationale should be included in order to change attitudes positively toward different varieties of English. Indeed, considering the varieties of English speaking interlocutors that Japanese individuals are likely to have, this advocating of world Englishes is well founded. 


\section{CONCLUSION}

I believe it is important for myself or any other English teacher to be aware of the many variables surrounding the profession. In my particular case, the decision to teach abroad in Japan makes it necessary to assess, at least these variables that I have investigated so far, namely, English as an international language within the context of World Englishes, English in Japan and its unique uses, and intelligibility of the different varieties of English.

The topic of English as an international language has special relevance to this research due to the nature of the subjects. For those Japanese university students who so wish to improve their English skills for communication, the inevitable arena for this English use will be international. While many of the English speaking interlocutors these Japanese students will face will come from Inner Circle countries, by sheer numbers it is more likely that these students will communicate in English with individuals from the Outer Circle and Expanding Circle. Therefore, it is from within this World Englishes perspective that I have chosen to include these different varieties in this intelligibility and comprehensibility study.

Furthermore, the involvement that the English language has with an Expanding Circle country such as Japan influences decisions and conclusions reached in this research. The role English plays in the Japanese educational 
system and the unique use of English in Japan through loanwords directly affects issues related to intelligibility and comprehensibility.

Finally, the growing body of research into the area of assessment of intelligibility and comprehensibility vis-à-vis the different varieties of English is of great importance to this research. It is from this base of research that I gained clues and direction for this study.

This study includes a large homogenous group of English learners not yet addressed in the research related to assessment of intelligibility and comprehensibility. By concentrating on this particular group of subjects, I hope to gain insights which will contribute to the growing body of research in the field.

The following research is an attempt to broaden my understanding of the situation I will face with a particular group of English learners. It is hoped that by thoroughly familiarizing myself with the issues involved, I can not only contribute to the growing body of research in the disciplines touched upon, but I will better understanding that I will have gained will better prepare this English instructor for the demands of the TESOL classroom. 
CHAPTER III

\section{METHODOLOGY}

\section{SUBJECTS}

Table I gives a summary of the personal data collected from the subjects that participated in this study, 211 Japanese university students. Due to the nature of the general uniformity of the Japanese educational system, these students are most likely similar to students from other universities with regard to English instruction. The selection of the subjects would be defined as a convenience sample as the selection process consisted of all of the students who showed up for class the day the instrument was given. Moreover, because of the large number of subjects participating, the results of this instrument should be statistically viable.

Of these subjects there were 35 females and 176 males. The students who ranged from 18 to 22 years of age, average 19.7, currently attend a private, engineering branch-campus university in western Japan, and were attending the same university at the time of the study. All of the students have studied English for an average of 7.7 years. Of the 211 subjects, 116 students had studied English outside of their normal school; 92 students had 
studied English at a 'cram' school (after-school entrance exam preparatory classes) for an average of 3.25 years; 18 students had studied English at an English conversation school for an average of 1.7 years; and, 6 students had studied English with a private instructor for an average of 1.3 years. In addition, 7 students had studied English abroad, 2 for one month, 1 for three months, 3 for a year, and 1 for two years. Furthermore, all of the students have had foreign English teachers. All of the students have had American (Am) instructors; 70 report having had instructors from Great Britain (GB); 42 have had Canadian (Can) instructors; 30 have had Indian instructors; 23 have had Australian (Aus) instructors; 8 have had Instructors from New Zealand (NZ); and one instructor from each of the following countries: Singapore (Sg), Switzerland (Sw), Germany (Ger), Korea (Kor), and Finland (Fin). It should be noted that 113 of the students have had a mixture of nationalities as English instructors with the average being 2.5 . Finally, 66 students have already taken the TOFEL exam with the average score being 399.

Surprizingly, if these above numbers are to be a guide in determining familiarity with different varieties of English, then the initial assumptions of hypothesis 3 are somewhat in error. It would appear that the subjects' familiarity with Indian English is greater than that of the Taiwanese. Due to convenience, this personal data collection could not done before hand.

At the time of the study, the subjects were studying English with an instructor from the United States. At this particular university the students are 
required to take two years, or four semesters, of English studying one and a half hours per week. The English classes range from general classes studying grammar, reading, writing, and speaking to specific classes such as an American film class.

\section{TABLE I}

\section{PERSONAL DATA SUMMARY OF STUDENTS}

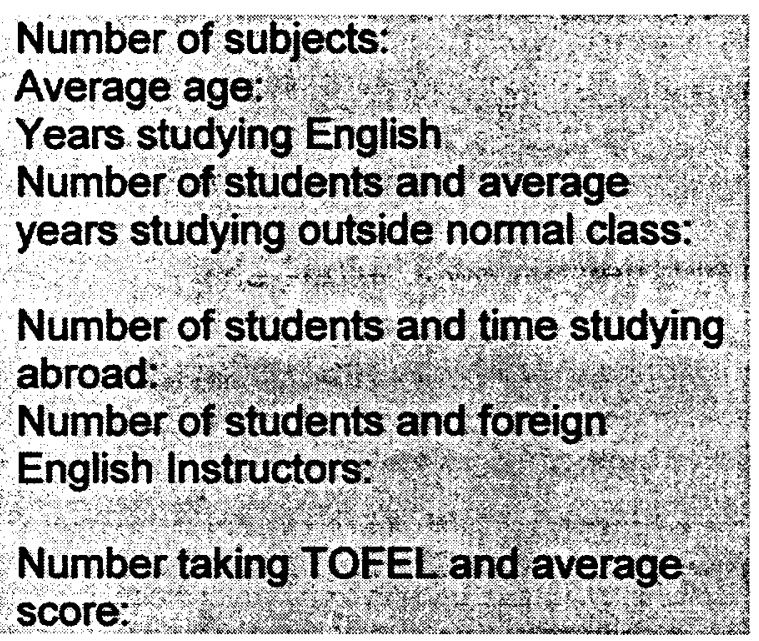

$211 ; 176 \mathrm{~m} \mathrm{35f}$

19.7 years

7.7 years

92 cram sch. 3.25 years

18 Eng. conversation sch. 1.7 years 6 private inst. 1.3 years

2 for $1 \mathrm{~m}, 1$ for 3 mos., 3 for 1 year, 1 for 2 years

211 Am, 70 GB, 42 Can, 30 India, 23 Aus, $8 \mathrm{NZ}, 1 \mathrm{Sg}, 1 \mathrm{Sw}, 1 \mathrm{Ger}, 1 \mathrm{Kor}, 1$ Fin

66 , score 399

\section{INSTRUMENTS AND MATERIALS}

Five taped recordings were prepared for this study; one was used for a trial run and the other four were used for the actual instrument. Each of the recordings contained two parts (see Appendix A): a short passage, and three short sentences. Table II shows that the content of the passages was limited to a $161-167$ word biography of five separate jazz musicians. This topic was 
intentionally chosen in order to present the subjects with new information. Moreover, the recordings were timed giving a length that ranged from $80-90$ seconds. Similarly, the three separate sentences for each recording were based on the musician described in the preceding passage. In addition, the passages were almost identically equal in difficulty based on four reading ease and grade level utilities found on MS word (MS 1994). These tests are described as follows:

Flesch Reading Ease: This test, "computes readability based on the average number of syllables per word and the average number of words per sentence. Scores range from 0 (zero) to 100." (MS1994) Average writing scores under this test range from $60-70$ with a higher score representing greater readability.

Flesch-Kincaid Grade Level: This test computes readability the same as above, but yields a score which indicates a grade-school level. (MS1994)

Coleman-Liau Grade Level: This test, "uses word length in characters and sentence length in words to determine a grade level." (MS1994)

Bormuth Grade Level: This test, "uses word length in characters and sentence length in words to determine a grade level." (MS1994)

The endeavor taken to craft four passages of almost identical length, speed read, readability and difficulty addresses concerns of internal validity. Nunan (1992:15) states that internal validity is concerned with the question: "Can any differences which are found actually be ascribed to the treatments 
under scrutiny?" In other words, by keeping as many variables as possible in the four passages uniform, the results obtained will be due to the dependent variable, the varying of the accent of the speaker.

TABLE II

\section{SUMMARY OF PASSAGE STATISTICS}

\begin{tabular}{|c|c|c|c|c|}
\hline Passages: & $\begin{array}{l}\text { Japanese } \\
\text { Speaker }\end{array}$ & $\begin{array}{l}\text { Taiwanese } \\
\text { Speaker }\end{array}$ & $\begin{array}{l}\text { Thdian } \\
\text { Speaker }\end{array}$ & $\begin{array}{l}\text { American } \\
\text { Speaker }\end{array}$ \\
\hline Word Count: & 167 & 161 & 162 & 162 \\
\hline Recording & 85 seconds & 90 seconds & 80 seconds & 80 seconds \\
\hline $\begin{array}{l}\text { Length and } \\
\text { average } \\
\text { words per } \\
\text { seconds: }\end{array}$ & 1.9 wps & 1.7 wps & $2.0 \mathrm{wps}$ & 2.0 wps \\
\hline $\begin{array}{l}\text { Flesch } \\
\text { Reading } \\
\text { Ease: }\end{array}$ & 71.9 & 71.4 & 71.7 & 70.8 \\
\hline $\begin{array}{l}\text { Flesch- } \\
\text { Kincaid Grade } \\
\text { Level: }\end{array}$ & 6 & 6 & 5.8 & 5.8 \\
\hline $\begin{array}{l}\text { Coleman-Liau } \\
\text { Grade Level: }\end{array}$ & 8.7 & 8 & 8.3 & 8 \\
\hline $\begin{array}{l}\text { Bormuth } \\
\text { Grade Level: }\end{array}$ & 8.5 & 8.5 & 8.5 & 8.5 \\
\hline
\end{tabular}

Based on these passages, a five-question multiple-choice test was devised. The purpose of this test was to check the comprehensibility aspect as defined by Smith and Nelson (1985) earlier. Each of these questions were translated into Japanese in order to eliminate the reading skill from this aurally 
focused test addressing the concerns of content validity, the ability of a test to measure what it purports to measure.

Based on the second part of the recordings, the three sentences, a 'cloze' type test was devised. In this type of test, a word or words are omitted from a written selection that the test taker sees. When listening to the actual sentences, the test taker hears the selection in its entirety requiring the omissions to be filled in with the word or words. The purpose of this test is to measure intelligibility as described by Smith and Nelson, or word utterance recognition. For this particular study, each of the three sentences had two words omitted requiring the subjects to fill in six blanks for each recording. Given that the subjects might be able to predict certain words due to the context of a sentence, the words omitted for the cloze were chosen in a way to eliminate this predictability. In addition, the sentences were not translated for the same reason (see Appendix A). Moreover, the language proficiency level of the subjects was taken into account, i.e., the sentences were well within their ability to read. These precautions were taken in order to more accurately measure the intelligibility aspect.

For these recordings, five separate educated speakers of English were taped reading the material. The practice recording was done by this researcher, a male MA student at PSU. The other four speakers included a female, Ph.D. professor at PSU who speaks an Indian variety of English; a Japanese female MA student at PSU; a Taiwanese female MA student at 
PSU; and, a female MA student at PSU who speaks a western variety of American English. Educated, female speakers were chosen for the actual instrument in order to keep the recordings as similar as possible to increase internal validity.

The choices of the accents represented in this instrument also have significance. These various accents represent Kachru's (1985) circles of English as described earlier. The American speaker represents an Inner Circle country; the Indian speaker an example of an Outer Circle country; and, the Taiwanese and Japanese speakers representing the Expanding Circle Countries. The Taiwanese speaker was also chosen to represent an Expanding Circle country due to the fact that all of the subjects are Japanese. It was felt that this would give a truer, if not interesting, measure of the effect that one particular Outer Circle accent has on the subjects

In addition to the recordings and their corresponding test, two questionnaires were also devised. One of these questionnaires was seven questions long dealing with personal data. The second questionnaire, adapted from Smith's (1992) study, asked the subjects to subjectively evaluate each of the speakers. Therefore, four of these subjective questionnaire, one for each of the speakers, were given to each subject. In addition, a cover sheet/consent form was created as well. This form, required by the Human Subjects Research Committee at PSU, contained information briefly describing the purpose of the study as well as a statement explaining 
voluntary participation and contact information for other questions the subjects might have. Finally, the questionnaires, cover/sheet consent form, and multiple choice questions were all translated and back-translated by two separate educated Japanese individuals fluent in both English and Japanese.

\section{PROCEDURE}

The instrument for this study was administered as part of the day's activities for the class. Therefore, the subjects' normal classroom was used at the normal class time. In addition, the individual administering the test was the subjects' regular EFL instructor. This instructor has several years' experience teaching EFL and ESL, as well as being fluent in Japanese. Therefore, any questions about the procedure were explained in Japanese to assure complete understanding.

The instrument was administered in an identical manner following a list of procedures for each class. This procedure was as follows:

1. The instructor briefly explained, in Japanese, the purpose of the study and clearly stated that it was unrelated to the class and their performance on the instrument would in no way affect their grades. The instructor then solicited any remaining questions from the subjects.

2. The subjects were given the consent form to read over for three minutes. 
3. The subjects read the questions for the practice recording for thirty seconds.

4. The subjects listened to the practice recording, then were given ten seconds to answer the questions.

5. The subjects read over the three practice cloze sentences for fifteen seconds.

6. The subjects listened to and completed the cloze test. Each of the three cloze sentences were played twice with a three second pause in between each sentence.

7. The subjects were given one minute to complete the evaluation questionnaire for the speaker.

8. Numbers two through seven of this procedure were repeated for the actual four recordings.

9. The subjects were given one minute to complete the personal data questionnaire.

\section{SUMMARY}

This instrument was designed in order to isolate the accents of different speakers of English from four different countries. These countries are representative of the three circles in which Kachru (1985) describes the English speaking world. In particular, this researcher is interested in how 
these different accents affect the intelligibility and comprehensibility assessments made by a specific group of EFL learners, in this case 211 Japanese university students. The intelligibility (word/utterance recognition) aspect will be measured by a cloze type test. The comprehensibility (word/utterance meaning) is measured by a multiple choice quiz based on one of four short passage read by one of the particular speakers of English. Moreover, a trial passage and cloze tests were also developed to remove any confusion that the subjects might have in first being introduced to this particular instrument. In addition to these two tests, two questionnaires were developed to gain additional information. One personal data questionnaire was developed in order to accurately describe the population of subjects; the other questionnaire was designed to gather subjective evaluations by the subjects of the four speakers. The various results gathered will be statistically analyzed in order to support or refute the hypotheses for this research. 


\section{CHAPTER IV}

\section{RESULTS}

In this chapter, the results of the instruments used during the research are reported: the cloze test used to assess intelligibility, the comprehension check questions based on the four different passages using different accents, and answers to the subjective evaluation of the four speakers by the subjects. In analyzing these results, an ANOVA (analysis of variance) is used to determine differences, if any, between scores resulting from the intelligibility test, and between scores based on the comprehensibility test. In addition, the Spearman's rank correlation coefficient is used to analyze the relationship between the answers on each of the first two questions of the subjective evaluation with the separate scores of the comprehensibility test and the intelligibility test. Finally, results from the remaining three questions from the subjective evaluation will be presented in various percentages.

\section{HYPOTHESES}

\section{Hypotheses}


The instruments used in this research were designed to measure objective and subjective assessments of intelligibility and comprehensibility. These assessments were made by 211 Japanese university students evaluating four different speakers. The speakers are educated speakers from the following countries: Japan, Taiwan, India and the United States. The research hypotheses are made as follows:

1. Phonological differences, 'accents', in educated speakers of English from Inner Circle, Outer Circle, and Expanding Circle countries as defined by Kachru (1985), (specifically the United States, India, Taiwan and Japan), affect the intelligibility assessments of these speakers made by beginning Japanese EFL university students.

2. Phonological differences, 'accents', in educated speakers of English from Inner Circle, Outer Circle, and Expanding Circle countries as defined by Kachru (1985), (specifically the United States, India, and Japan), affect the comprehensibility assessments of these speakers made by beginning Japanese EFL university students.

3. Familiarity with any one 'accent' by the above students will influence their intelligibility and comprehensibility assessments. Thus, due to the contact that these Japanese listeners have had with these accents, it is believed that they will find the Japanese speaker most understandable followed by the U.S., Taiwan, and India. 
4. There is a positive relationship between student subjective assessment of speaker intelligibility and comprehensibility, and student achievement on comprehension and intelligibility tests based on the taped material.

In determining whether or not to accept or reject these hypotheses, the ANOVA and Spearman's rank correlation coefficient statistical tools were employed.

\section{ANOVA ANALYSIS}

Intelligibility

An initial look at a comparison of mean scores on the cloze tests is shown in Figure 2. These tests measured the subjects' assessment of intelligibility of the Japanese, Taiwanese, Indian and American speakers. The mean score for the cloze test that assessed the intelligibility of the Japanese speaker is highest with 5.03 . The mean score for the cloze test that assessed the intelligibility of the American speaker is next with 4.22. The mean score for the cloze test that assessed the intelligibility of the Taiwanese speaker is 4.07 . And, the mean score for the cloze test that assessed the intelligibility of the Indian speaker is 3.79. All scores are out of a possible score of six. In analysis of variance (ANOVA), these sets of means are jointly tested for 
significant difference. Then a follow up test is run to identify the source of difference.

FIGURE 2

COMPARISON OF MEANS FOR CLOZE TEST SCORES

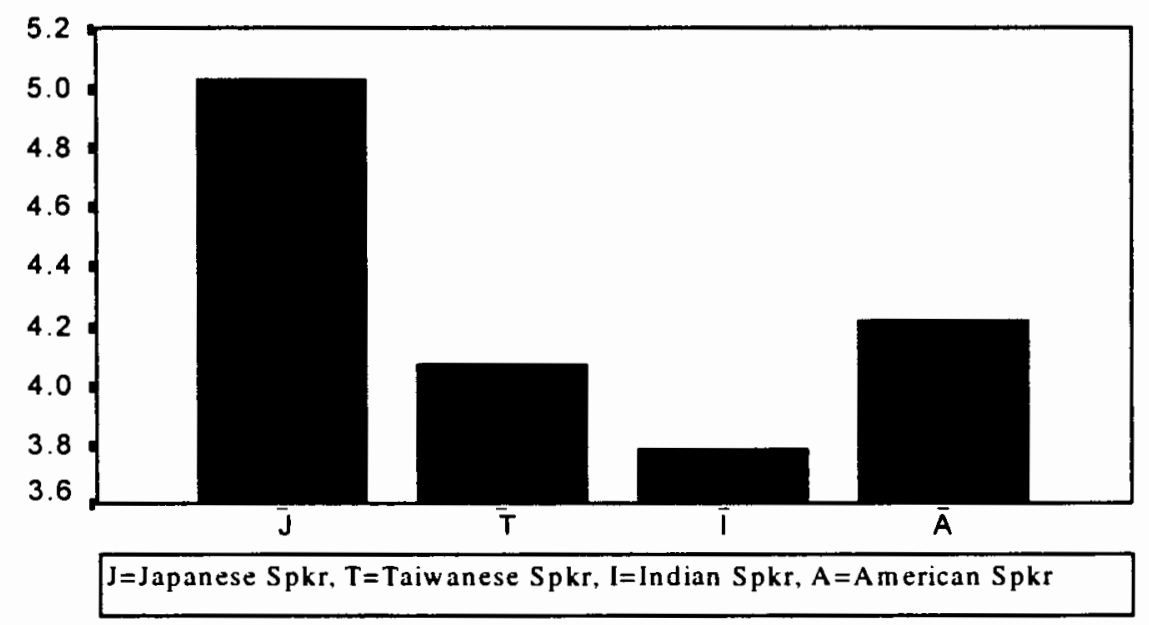

The ANOVA is a statistical tool used to compare variance within or between multiple groups. In essence, the ANOVA runs multiple t-tests. The ANOVA will determine if there is a statistically significant difference between any and all of the means and the order that these means occur.

The intelligibility assessments made by the 211 subjects defined earlier and in hypothesis 1 were arrived at by obtaining mean scores from four separate cloze tests. Thus, four separate groups of mean scores were obtained. Group 1 represents the mean cloze test scores resulting from the assessment of the Japanese speaker; group 2 represents the mean cloze test scores resulting from the assessment of the Taiwanese speaker; group 3 
represents the mean cloze test scores resulting from the assessment of the Indian speaker; and, group 4 represents the mean cloze test scores resulting from the assessment of the American speaker. Based on this configuration, a one-way ANOVA was run. Table III summarizes the results of the ANOVA for the cloze test scores.

The ANOVA compares the within-group means to the between-group means; from this comparison an F-Ratio is obtained. If the F-Ratio is close to 1 , then the null hypothesis is true. The F-Ratio for the cloze test is 57.9127 ; not close to 1 , and the F-Probability is at a level below 0.00005 . Therefore, the null hypothesis is rejected and hypothesis 1 is supported with respect to intelligibility.

\section{TABLE III}

\section{ANOVA FOR CLOZE TEST SCORES}

$\begin{array}{lrrrrr}\text { Source } & \text { D.F. } & \begin{array}{l}\text { Sum of } \\ \text { Squares }\end{array} & \begin{array}{l}\text { Mean } \\ \text { Squares }\end{array} & \begin{array}{l}\text { F } \\ \text { Ratio }\end{array} & \begin{array}{l}\text { F } \\ \text { Prob. }\end{array} \\ \text { Between Groups } & 3 & 180.4882 & 60.1627 & 57.9127 & .0000 \\ \text { Within Groups } & 840 & 872.6351 & 1.0389 & & \\ \text { Total } & 843 & 1053.1232 & & & \end{array}$

The second part of an ANOVA analysis employs tests called multiple comparison procedures. These tests determine which means are significantly different from each other. The test chosen to analyze these results, was the 
Bonferroni test. This test, "adjusts the observed significance level based on the number of comparisons you are making" (SPSS, 1993). When making several comparisons, the chance that there will be a significant difference increases.

Table IV summarizes the results for the cloze tests. The results show statistical differences among the scores that assessed the perceived intelligibility of all of the speakers except the Taiwanese (group 2), and the American (group 4). There was no significant difference between cloze test scores that assessed the intelligibility of the Taiwanese and American speakers. Therefore the resulting order of intelligibility gained from this analysis is as follows: the Japanese speaker was assessed most intelligible; the Taiwanese and American speakers were assessed next most intelligible; the Indian speaker was assessed to be the least intelligible.

TABLE IV

BONFERRONI TEST FOR CLOZE TEST SCORES

Mean Group

3.7915 Grp $3 \underline{3} \quad \underline{2} \quad \underline{4} \quad \underline{1}$

4.0664 Grp 2 *

4.2180 Grp 4

5.0332 Grp 1

* = significant difference between groups

(Grp 1 = Japanese Spkr, Grp 2 = Taiwanese Spkr, Grp 3 = Indian Spkr, Grp 4 = American Spkr) 
Based on these results, hypothesis 3 is only partially supported with regard to the Japanese and Indian speakers.

Comprehensibility

The comprehensibility assessments described in hypothesis 2 were arrived at by obtaining the mean scores of the four comprehensibility tests based on the four passages. With a look at the comparison between the subjects' mean scores on the passage test in Figure 3, it is apparent that, while there appears to be differences in these means, the order is such that hypothesis 3 is not entirely supported. The mean score based on the Japanese speaker was 88.91 ; the mean for the Taiwanese was 82.84 ; the Indian mean was 73.65 , and the mean score based on the American speaker was a low of 57.96. All scores were out of a possible 100. An ANOVA determines the differences between these means. 
FIGURE 3

COMPARISON OF MEANS FOR PASSAGE TEST SCORES

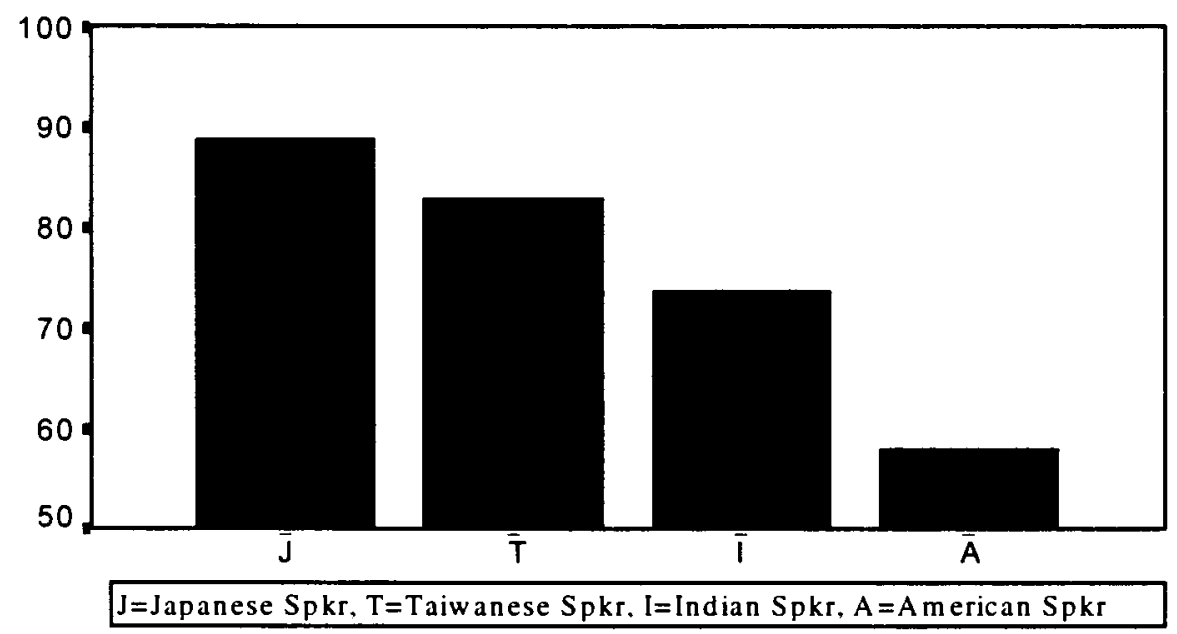

As with intelligibility, the ANOVA was used to analyze these mean

scores as well. Again we can reject the null hypothesis with the F-Ratio and F-Probability being 101.6795 and less than 0.00005 respectively. Therefore, hypothesis 1 is supported with respect to comprehensibility. Table $V$ summarizes these results.

\section{TABLE $V$}

ANOVA FOR PASSAGE TEST SCORES

\begin{tabular}{|c|c|c|c|}
\hline Sou & D.F. & $\begin{array}{l}\text { Sum of } \\
\text { Squares }\end{array}$ & $\begin{array}{l}\text { Mean } \\
\text { Squares }\end{array}$ \\
\hline
\end{tabular}

Between Groups $\quad 3 \quad 114845.8531 \quad 38281.9510 \quad 101.6795 .0000$ Within Groups $\quad 840 \quad 316256.8720 \quad 376.4963$

Total $\quad 843 \quad 431102.7251$ 
For the passage test scores, the Bonferroni test was used as well. Again, in matrix format, the results in Table VI show that all of the four speakers were found to be significantly different from each other. When looking at the order of speaker comprehensibility, the following emerges: The Japanese was found to be most comprehensible, followed by the Taiwanese, Indian, and American speakers respectively. These results indicate that hypothesis 3 is supported only with regard to the Japanese speaker.

\author{
TABLE VI
}

BONFERRONI TEST FOR PASSAGE TEST SCORES

Mean Group

$57.9621 \quad \underline{4} \quad \underline{3} \quad \underline{2} \quad 1$ 73.6493 Grp 3 82.8436 Grp 2 88.9100 Grp 1 * * *

* = significant difference between groups

(Grp 1 = Japanese Spkr, Grp 2 = Taiwanese Spkr, Grp $3=\operatorname{Indian}$ Spkr, Grp $4=$ American Spkr)

\title{
CORRELATION ANALYSIS
}

The following correlation analysis concerns itself with hypothesis 4 which claims that there is a relationship between the subjects' subjective assessment of speaker comprehensibility and intelligibility, and the actual 
scores from tests used to measure these factors in this research. The subjective evaluations used for the correlation analysis comes from the first two questions of the questionnaire (see Appendix B). This questionnaire was given to subjects directly after the passage and cloze tests were completed for a particular speaker. The first two questions from the subjective questionnaire are:

1. Could you understand what the presenter said?<smiles>[Mg][Mg]</smiles>
easily with some difficulty with great difficulty not at all

2. How much of the recording did you understand?

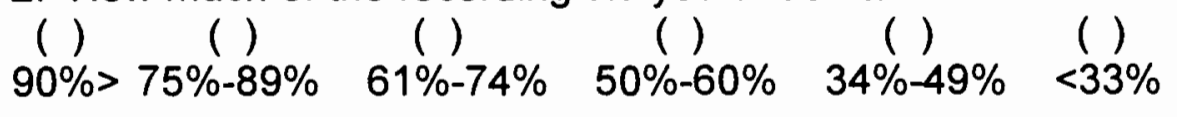

Each answer was coded for analysis by assigning the number 1 for the far left choice proceeding across to the right up to 4 for question 1 and 6 for question 2. Therefore, hypothesis 4 assumes that a checked answer of easily or $90 \%>($ coded 1 ) would correspond to a high score on the intelligibility and cloze tests. It should be noted however, that correlations are not the same as causation; one cannot say, for example in this study, that a high subjective assessment will lead to a high score if there is a strong correlation. But, a strong correlation would give evidence to a researcher that there is evidence to draw some conclusions.

The answers to these questions are considered to be rank data, or a form of ordinal data. That is, the amount of difference between the choices to these questions is not exactly known. Therefore, the Bivariate Correlation 
procedure known as the Spearman's rank correlation coefficient is the appropriate test to use. Each of these questions will be correlated with the separate data obtained from the intelligibility and comprehensibility tests. Therefore, each speaker will have a total of four correlations; the correlation between intelligibility scores with question 1 then 2 , and then the same with the comprehensibility scores. Moreover, correlation scores range from -1 to +1. A -1 indicates perfect negative correlation; $X$ decreases as $Y$ increases. A perfect positive correlation, +1 , indicates that $X$ increases as $Y$ increases. In addition, these correlation scores, usually represented by the symbol $r$, can be transformed into a number that describes the strength of the relationship between two variables. By squaring the coefficient $r$, thus $r^{2}$, a new number called the coefficient of determination is reached. This number represents the percentage of the variance of one variable that is predictable from the other. The following guide, values of $r^{2} \times 100$ for values of $r$ from .10 to 1.00 , is as follows:

$\begin{array}{cccc}\frac{r}{10} & \frac{r^{2} \times 100}{1} & \frac{r}{60} & \frac{r^{2} \times 100}{36} \\ .20 & 4 & .70 & 49 \\ .30 & 9 & .80 & 64 \\ .40 & 16 & .90 & 81 \\ .50 & 25 & 1.00 & 100\end{array}$

Finally, in interpreting the results for the following correlations it is important to first look at the significance column. Any correlation with a number above the .05 significance level is considered to be happening by 
chance and thus not valid. If the correlation has a significance level below .05 , then the correlation score can be considered. What is deemed to be a strong or weak correlation depends on the type of research being conducted. For example, if there were a correlation of .2 ( $4 \%$ of the population) found for a group of subjects predicting lottery numbers and actual results, this would be considered a strong correlation due to the nature of odds and the lottery. However, for this research I believe that a correlation number of .6 or higher would give evidence to the subjects' subjective assessments predicting actual test scores.

Intelligibility

Table VII shows the results of the correlation between questions number 1 and 2 and the cloze scores from the Japanese speaker. The correlation between the cloze scores and question number 1 is -.2792 . This number indicates that as the test scores from the cloze test went up, the subjective rank given by the subjects went down in number according to the coding of the answers. Due to the nature of the coding, this means that there was a trend towards the choice easily as the actual cloze test scores went up. Or, the higher the cloze test score, the higher the subjects subjectively assessed their understanding of the speaker. In addition, this is significant at a level below .01 . For question 2 , the correlation was found to be -.3125 at a significance level below .01 indicating a trend towards $90 \%>(\operatorname{coded} 1)$ as cloze scores increased. However, both of these correlation results are below 
the .6 level and thus are considered very weak for this research. Therefore, hypothesis 4 is not supported with regard to the Japanese speaker and cloze scores.

\section{TABLE VII}

SPEARMAN'S CORRELATION COEFFICIENT FOR JAPANESE SPEAKER

\begin{tabular}{|c|c|c|c|}
\hline Question & Num. of pairs & Correlation & Significa \\
\hline 1 & 211 & -.2792 & .00 \\
\hline 2 & 211 & -.3125 & .00 \\
\hline
\end{tabular}

Table VIII shows the results for the correlation between questions 1 and 2 and the cloze scores based on the Taiwanese speaker. The results follow the above format and show similar results. The correlation for question number 1 is -.2029 at a significance level of .003 . Question number 2 shows a correlation of -.2638 at .000 . Again, due to the weakness of both correlations, hypothesis 4 is not supported with regard to the Taiwanese speaker.

TABLE VIII SPEARMAN'S CORRELATION COEFFICIENT FOR TAIWANESE SPEAKER Question Num. of pairs $\quad$ Correlation Significance 
Table IX describes the results obtained for the correlation obtained between the cloze test scores from the Indian speaker and questions 1 and 2 . For both questions, the level of significance is well above the crucial level of .05 indicating that any correlation is occurring by chance. Therefore it is concluded that hypothesis 4 is not supported with regard to the Indian speaker.

TABLE IX

SPEARMAN'S CORRELATION COEFFICIENT FOR INDIAN SPEAKER

Question Num. of pairs $\quad$ Correlation Significance

$\begin{array}{llll}1 & 211 & -.0555 & .423 \\ 2 & 211 & -.1085 & .116\end{array}$

Finally in Table $X$, the results for the correlation between the cloze test scores and questions 1 and 2 assessing the American speaker are given. Again, even though the significance levels are below the .01 level, the correlation scores are too weak to support hypothesis 4 with regard to the American speaker. This correlation score for question number 2 shows the strongest correlation between any of the questions and the cloze scores assessing the four speakers. 
TABLE $X$

SPEARMAN'S CORRELATION COEFFICIENT FOR AMERICAN SPEAKER Question Num. of pairs $\quad$ Correlation Significance

$\begin{array}{llll}1 & 211 & -.3142 & .000 \\ 2 & 211 & -.4227 & .000\end{array}$

Comprehensibility

As with the question of intelligibility, correlations between the subjective evaluations of comprehensibility and the passage test scores used to measure this aspect were computed. Again, the two questions from the post test questionnaire described above (see Appendix B) were used for the subjective evaluation.

Table XI summarizes the correlation results found between the passage test scores and questions 1 and 2 based on the Japanese speaker. The two correlation coefficients for questions 1 and 2 are -.2549 and -.2678 respectively; both at a significance level below .01 . These correlations are too weak and thus hypothesis 4 is not supported with regard to comprehensibility and the Japanese speaker. 
TABLE XI

SPEARMAN'S CORRELATION COEFFICIENT FOR JAPANESE SPEAKER

\begin{tabular}{|c|c|c|c|}
\hline Question & Num. of pairs & Correlation & Significance \\
\hline $\begin{array}{l}1 \\
2\end{array}$ & $\begin{array}{l}211 \\
211\end{array}$ & $\begin{array}{l}-.2549 \\
-.2678\end{array}$ & $\begin{array}{l}.000 \\
.000\end{array}$ \\
\hline
\end{tabular}

Table XII presents the next group of correlation results obtained from the scores based on the Taiwanese speaker. These results give a correlation coefficient of -.1380 for question 1 and a similar -.1385 for question 2 ; both at a significance level below .05 . Again, the weakness of the correlations indicates that hypothesis 4 is not supported for the Taiwanese speaker.

TABLE XII

SPEARMAN'S CORRELATION COEFFICIENT FOR TAIWANESE SPEAKER

\begin{tabular}{|c|c|c|c|}
\hline Question & Num. of pairs & Correlation & Significance \\
\hline $\begin{array}{l}1 \\
2\end{array}$ & $\begin{array}{l}211 \\
211\end{array}$ & $\begin{array}{l}-.1380 \\
-.1385\end{array}$ & $\begin{array}{l}.045 \\
045\end{array}$ \\
\hline
\end{tabular}

Based on the passage test scores from the Indian speaker, the correlation results are presented in Table XIII. The correlation numbers for this set of results are -.2764 and -.3813 for questions 1 and 2 respectively. These numbers are at a significance level below .01 . While significant, the 
correlations are too weak to support hypothesis 4 with regard to the Indian speaker.

\section{TABLE XIII}

SPEARMAN'S CORRELATION COEFFICIENT FOR INDIAN SPEAKER

Question Num. of pairs $\quad$ Correlation Significance

$\begin{array}{llll}1 & 211 & -.2764 & .000 \\ 2 & 211 & -.3813 & .000\end{array}$

Finally, Table XIV presents the correlation results between questions 1 and 2 and the Passage Test scores from the American speaker. These results give a correlation number of -.1967 for question 1 and a number of .2055 for question 2 . These scores are at a significance level below .01 . Hypothesis 4 is therefore not supported based on these weak correlations.

TABLE XIV

SPEARMAN'S CORRELATION COEFFICIENT FOR AMERICAN SPEAKER

Question

1

2 $\underline{\text { Num. of pairs }}$

211

211
Correlation

$-.1967$

$-.2055$
Significance

.004

.003 


\section{OTHER ASSESSMENTS}

The final section of results presents the findings from the last three questions on the post passage and cloze test questionnaire. These questions (see Appendix B) ask subjects to: give reasons for any difficulties they had in understanding the speakers, to make guesses as to the nationality of the speakers, and to evaluate the speakers educational level, type of English speaker, and type of English spoken.

3. Did you have difficulty understanding the recording?

Yes_No If Yes, check the appropriate
reasons. (You may check as many as you wish.)
I could not understand the meaning of what was said.
The speaker spoke too quickly.
The accent of the speaker was hard to understand.
Other (please write)

4. What was the speaker's nationality?

5. Based on what you heard, it seems that the speaker is (check as many as you wish):

Highly educated A native speaker Educated A non-native speaker
A speaker of Standard English A speaker of non-Standard English

\section{Question 3}

Question 3 asked subjects to decide if they had trouble understanding the speaker to whom they had just listened, and then choose the reason they perceived was the cause of difficulty (subjects could choose more than one 
reason). For each of the four speakers, the results are presented in terms of actual number of subjects who chose a particular reason and the resulting percentages.

Table XV presents answers chosen in question 3 based on the Japanese speaker. A clear majority, almost $70 \%$, of the subjects reported that they had no difficulty understanding the Japanese speaker. Twenty two or $10.4 \%$ claimed that they could not understand the meaning of what was said; 19 or $9 \%$ reported that the speaker spoke too quickly; 24 or $11.3 \%$ had trouble with the accent; 9 or $4 \%$ claimed a reason other than those offered; and, 2 or $.9 \%$ claimed they had difficulty but did not choose a reason.

TABLE XV

ANSWERS TO QUESTION 3 BASED ON JAPANESE SPEAKER

\begin{tabular}{lll} 
Answers to question 3 & $\frac{\text { Number and percent }}{\text { responding }}$ & $\frac{\text { Percent }}{69.2 \%}$ \\
\cline { 1 - 2 } $\begin{array}{l}\text { No difficulty } \\
\text { understanding: }\end{array}$ & 146 & $10.4 \%$ \\
$\begin{array}{l}\text { Could not understand } \\
\text { meaning: }\end{array}$ & 22 & \\
$\begin{array}{l}\text { Spoke too quickly: } \\
\text { Trouble with accent: }\end{array}$ & 19 & $9 \%$ \\
$\begin{array}{l}\text { Other: } \\
\text { Had trouble/no }\end{array}$ & 9 & $11.3 \%$ \\
reason: & 2 & $4 \%$ \\
& & $.9 \%$ \\
\end{tabular}

Table XVI gives the results for question 3 based on the Taiwanese speaker. Only 27 or $12.8 \%$ of the subjects reported that they did not have any 
difficulties understanding the speaker. Forty or $18.9 \%$ claimed that they could not understand the meaning; 62 or $29.4 \%$ reported that the speaker spoke too quickly; 123 or $58.3 \%$ reported that they had trouble with the accent; and, 30 or $14.2 \%$ claimed the reason as other.

Table XVI

ANSWERS TO QUESTION 3 BASED ON TAIWANESE SPEAKER

\begin{tabular}{|c|c|c|}
\hline Se- & Number and percent & \\
\hline Answers to question 3 & responding & Percent \\
\hline $\begin{array}{l}\text { No difficulty } \\
\text { understanding: }\end{array}$ & 27 & $12.8 \%$ \\
\hline $\begin{array}{l}\text { Could not understand } \\
\text { meaning: }\end{array}$ & 40 & $18.9 \%$ \\
\hline Spoke too quickly: & 62 & $29.4 \%$ \\
\hline Trouble with accent: & 123 & $58.3 \%$ \\
\hline & 30 & $14.2 \%$ \\
\hline Ino & 0 & $0 \%$ \\
\hline
\end{tabular}

To continue, the results given for the Indian speaker are presented in Table XVII. Only 15 or $7.1 \%$ of the subjects claimed that they had no difficulty understanding the speaker; 77 or $36.5 \%$ claimed that they could not understand the meaning of what they heard; 107 or $50.7 \%$ reported that the speaker spoke too quickly; 121 or $57.3 \%$ of the subjects had trouble with the accent; 13 or $6.1 \%$ reported a reason of other, and, 1 or $.5 \%$ claimed that they had trouble with no reason. 
TABLE XVII

\section{ANSWERS TO QUESTION 3 BASED ON INDIAN SPEAKER}

\begin{tabular}{|c|c|c|}
\hline Answers to question 3 & $\frac{\text { Number an }}{\text { responding }}$ & Percent \\
\hline $\begin{array}{l}\text { No difficulty } \\
\text { understanding: }\end{array}$ & 15 & $7.1 \%$ \\
\hline $\begin{array}{l}\text { Could not understand } \\
\text { meaning: }\end{array}$ & 77 & $36.5 \%$ \\
\hline Spoke too quickly: & 107 & $50.7 \%$ \\
\hline Trouble with accent: & 121 & $57.3 \%$ \\
\hline Other: & 13 & $6.1 \%$ \\
\hline $\begin{array}{l}\text { Had trouble/no } \\
\text { reason: }\end{array}$ & 1 & $.5 \%$ \\
\hline
\end{tabular}

Finally, Table XVIII presents the results of the answers to Question 3 based on the American speaker. Twenty three or $10.9 \%$ of the subjects reported that they had no difficulty understanding the speaker. Those who claimed that they could not understand the meaning numbered 64 or $30.3 \%$; a majority of 146 or $69.2 \%$ reported that the speaker spoke too quickly; 68 or $32.2 \%$ had trouble with the accent; and, 7 or $3.3 \%$ claimed the reason as being other. 
TABLE XVIII

ANSWERS TO QUESTION 3 BASED ON AMERICAN SPEAKER

$\begin{array}{lll}\text { Answers to question } 3 & \frac{\text { Number and percent }}{\text { responding }} & \frac{\text { Percent }}{10.9 \%} \\ \begin{array}{lll}\text { No difficulty } \\ \text { understanding: }\end{array} & 23 & \\ \begin{array}{l}\text { Could not understand } \\ \text { meaning: }\end{array} & 64 & 30.3 \% \\ \begin{array}{l}\text { Spoke too quickly: } \\ \text { Trouble with accent: }\end{array} & 146 & 68 \\ \begin{array}{l}\text { Other: } \\ \text { Had trouble/no }\end{array} & 7 & 69.2 \% \\ \text { reason: } & 0 & 32.2 \% \\ & & 0 \% \\ \end{array}$

\section{Question 4}

Question 4 simply asked the subjects to guess the nationality of the speaker to whom they had just listened. Furthermore, the subjects had not been given any list of countries from which to choose. The results are presented by individual speaker.

The first group of results are the guesses made of the Japanese speaker. Figure 4 displays the comparisons. Thirteen or $6.2 \%$ of the subjects made no guess at all (none). The following are the reported guesses of nationality in descending order are given by number and percentage of subjects responding: Japan (j) $167 / 79.1 \%$, America (a) $17 / 8.1 \%$, China (chin) $5 / 2.4 \%$, United Kingdom (uk) $4 / 1.9 \%$, France (f) $2 / .9 \%$, Canada (can) $1 / .5 \%$, Korea $1 / .5 \%$, and Spain (s) $1 / .5 \%$. 
FIGURE 4

NATIONALITY GUESSES MADE FOR JAPANESE SPEAKER

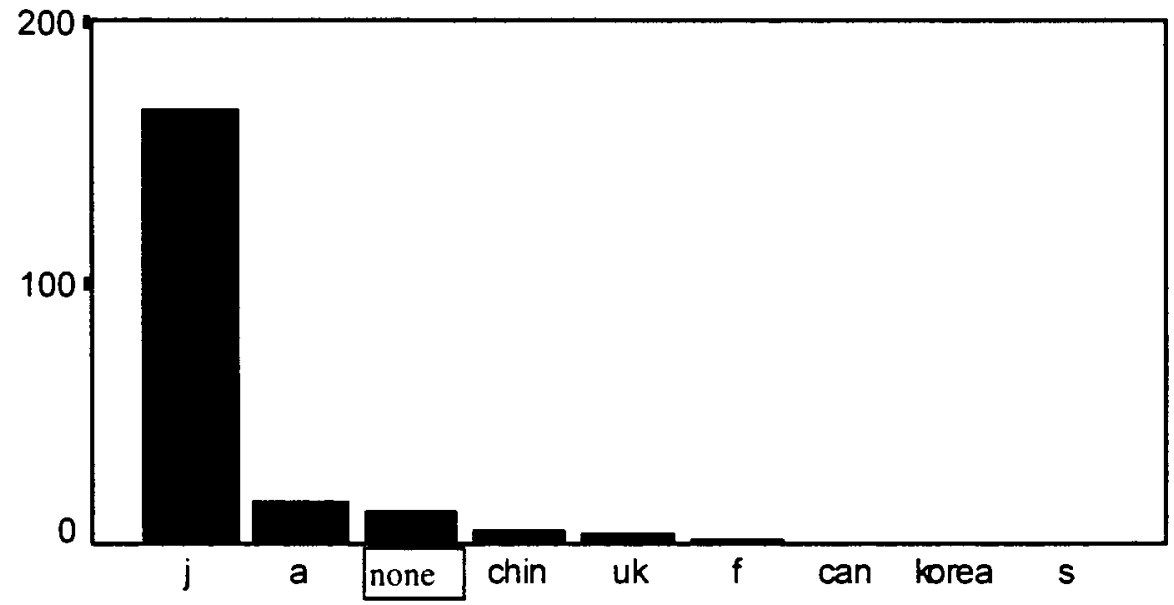

Figure 5 gives the results for question 4 this time for the Taiwanese speaker. While 39 or $18.5 \%$ of the subjects made no guess (none), the variety of guesses have increased. Again, in descending order by number and percentages the following results are: America (a) $77 / 36.5 \%$, \%, France (f) $28 / 13.3 \%$, United Kingdom (uk) $26 / 12.3 \%$, Japan (j) $9 / 4.3 \%$, Germany (g) 6/2.8\%, Canada (can) 5/2.4\%, China (chin) 5/2.4\%, Europe (eur) $3 / 1.4$ India (I) $3 / 1.4 \%$, Asia $2 / .9 \%$, Mexico (mex) $2 / .9 \%$, Spain $2 / .9 \%$, Australia (aus) $1 / .5 \%$, Philippines (phil) $1 / .5 \%$, Singapore (sing) $1 / .5 \%$, and Sweden (swed) $1 / .5 \%$. 
FIGURE 5

NATIONALITY GUESSES MADE FOR TAIWANESE SPEAKER

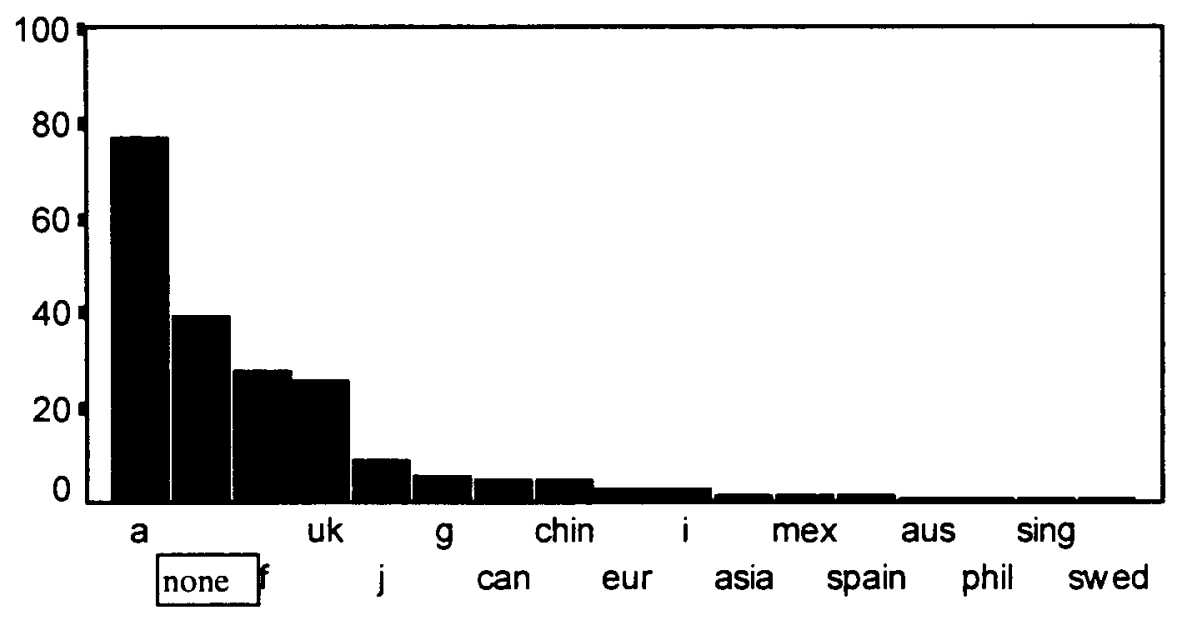

The results for the Indian speaker are given in Figure 6 . This time, 54 or $25.6 \%$ of the subjects made no guess (none) as to the nationality of the speaker. The rest of the results are as follows: America (a) $78 / 37 \%$, United Kingdom (uk) $23 / 10.9 \%$, France (f) $15 / 7.1 \%$, India $5 / 2.4 \%$ (i), Spain (sp) $5 / 2.4 \%$, Australia (aus) $4 / 1.9 \%$, Canada (can) $4 / 1.9 \%$, Germany (g) $4 / 1.9 \%$, Italy (it) $3 / 1.4 \%$, Japan (j) $3 / 1.4 \%$, Mexico (mex) $3 / 1.4 \%$, China (c) $21.9 \%$, Africa (af) $1 / .5 \%$, Brazil (br) $1 / .5 \%$, Europe (eur) $11.5 \%$, New Zealand (nz) $1 / .5 \%$, Middle East (me) $1 / .5 \%$, Philippines (pn) $1 / .5 \%$, South America (sa) $1 / .5 \%$, and Switzerland (sw) $1.5 \%$. 
FIGURE 6

NATIONALITY GUESSES MADE FOR INDIAN SPEAKER

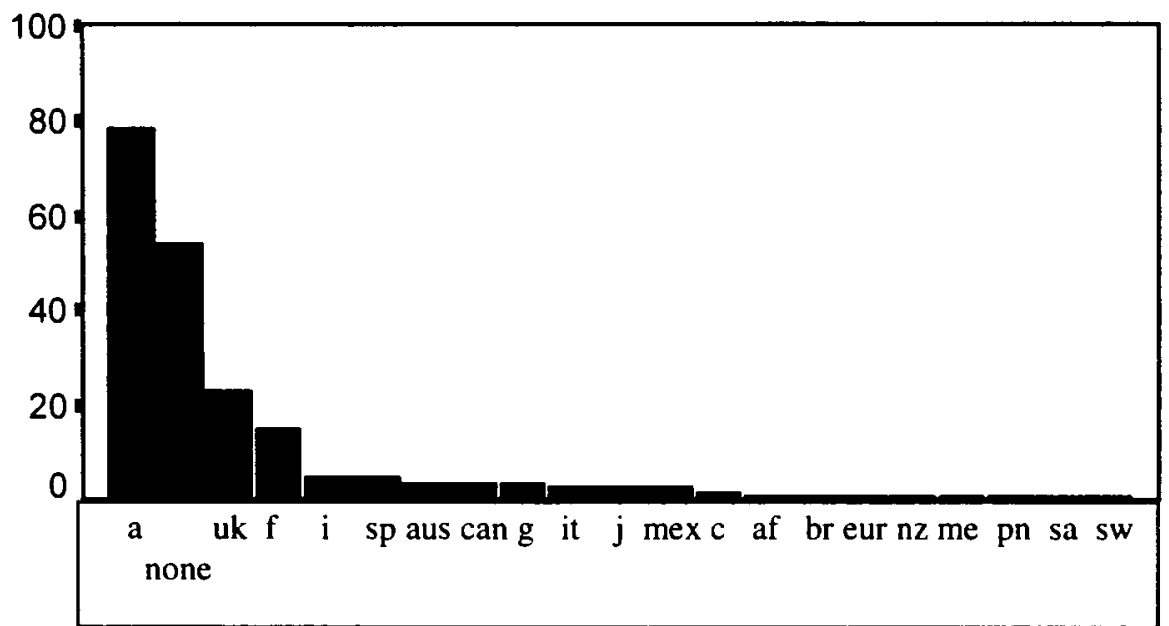

Finally, in Figure 7, the nationality guesses made for the American speaker are presented. Thirty two or $15.2 \%$ of the subjects made no guesses (none) about the nationality of the speaker. The results for those who did guess are as follows: America (a) $124 / 58.8 \%$, United Kingdom (uk) $30 / 14.2 \%$, Canada (can) $7 / 3.3 \%$, Australia (aus) $5 / 2.4 \%$, Japan (j) $4 / 1.9 \%$, France (f) $3 / 1.4 \%$, Italy (ital) $3 / 1.4 \%$, China (chin) $1 / .5 \%$, The Netherlands (neth) $1 / .5 \%$, and Spain $1 / .5 \%$. 
FIGURE 7

NATIONALITY GUESSES MADE FOR AMERICAN SPEAKER

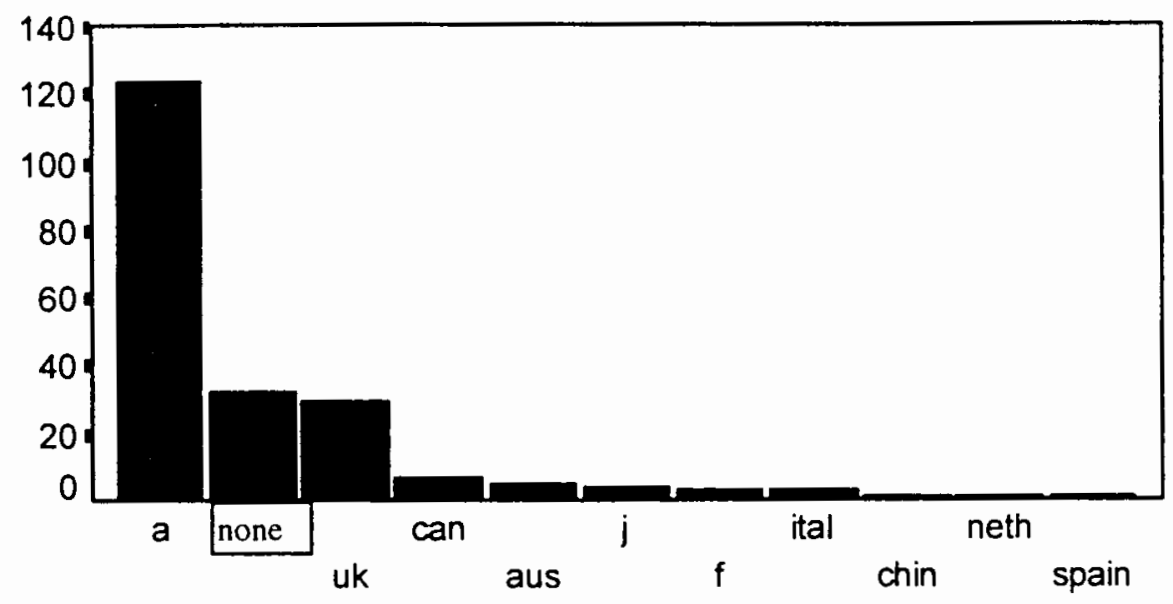

\section{Question 5}

Question 5 is the final question of the subjective questionnaire. The answers to this question are broken up into three groups. The first three choices of the question ask the subjects to assess the educational level of the speaker to whom they had just listened. The second group of answers, choices four and five, ask the subjects to decide if the speaker is a native or a non-native speaker. The final two choices, six and seven, ask the subjects to assess whether or not the speaker uses a standard or non-standard English. Therefore, the subjects could make a maximum of three choices on question 5 ; however, several subjects made only one or two choices. The results based on each of the four speakers are divided into the three groups 
mentioned above: 1)Highly educated/educated/not well educated (HE/E/NWE). 2)Native speaker/non-native speaker (NS/NNS). 3)Standard English/non-standard English (SE/NSE). Table XIX presents the results of Question 5 in a manner similar to the way Smith (1992:87) presents his findings. For the Japanese speaker, $13 \%$ of the subjects chose $\mathrm{HE}, 46 \% \mathrm{E}$, $11 \%$ NWE, $8 \%$ NS, $83 \%$ NNS, $28 \%$ SE, and $24 \%$ NSE. The results for the Taiwanese speaker show $7 \%$ of the subjects choosing HE, $36 \% \mathrm{E}, 24 \%$ NWE, $52 \%$ NS, $36 \%$ NNS, $25 \%$, SE, and $35 \%$ NSE. For the Indian speaker $7 \%$ of the subjects chose $\mathrm{HE}, 39 \% \mathrm{E}, 18 \%$ NWE, $56 \% \mathrm{NS}, 31 \mathrm{NNS}, 25 \% \mathrm{SE}$, and $38 \%$ NSE. Finally, $23 \%$ of the subjects chose HE for the American, $42 \% E$, $5 \%$ NWE, $81 \%$ NS, $9 \%$ NNS, $44 \%$ SE, and $17 \%$ NSE.

\section{TABLE XIX}

\section{PERCENTAGES GIVEN FOR QUESTION 5}

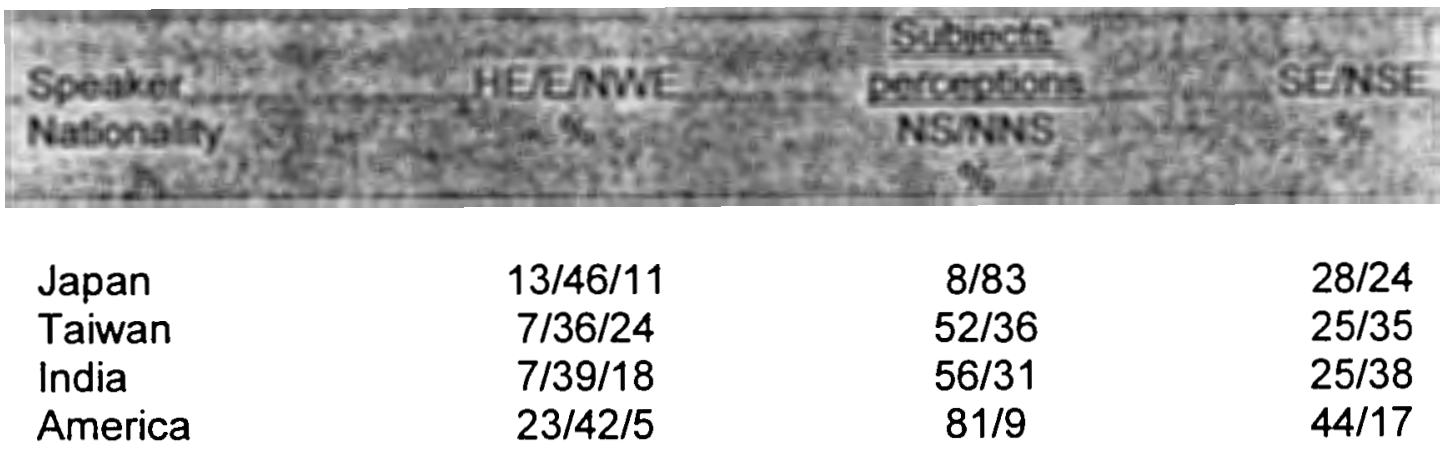


SUMMARY

The ANOVA results for intelligibility showed a significant difference in means for all but the American and Taiwanese speaker. Thus for intelligibility, Hypotheses 1 and 3 were only partially supported in that not all of the speakers were assessed differently. For comprehensibility, Hypothesis 1 was supported with the ANOVA results showing a significant difference between all four speakers. However, when determining the order of mean scores for comprehensibility, the ANOVA results did not support Hypothesis 3 .

Furthermore, all of the correlation results were too weak to show any relationship between objective test scores and subjective evaluations made by the subjects. 


\section{CHAPTER V}

\section{DISCUSSION OF RESULTS}

In this chapter, a discussion of the various results obtained will be presented. This discussion will include conclusions that can be made from the various findings, the implications that these findings have for World Englishes and the field of Teaching English to Speakers of Other Languages, limitations of the research, and suggestions for further research.

\section{DISCUSSION OF THE FINDINGS}

Intelligibility and Comprehensibility Results

The findings regarding intelligibility and comprehensibility looked at in the previous chapter pertained to hypotheses 1,2 and 3. Again, for reference these hypotheses are as follows:

1. Phonological differences, 'accents', in educated speakers of English from Inner Circle, Outer Circle, and Expanding Circle countries as defined by Kachru (1985), (specifically the United States, India, Taiwan and Japan), affect the intelligibility assessments of these speakers made by beginning Japanese EFL university students. 
2. Phonological differences, 'accents', in educated speakers of English from Inner Circle, Outer Circle, and Expanding Circle countries as defined by Kachru (1985), (specifically the United States, India, and Japan), affect the comprehensibility assessments of these speakers made by beginning Japanese EFL university students.

3. Familiarity with any one 'accent' by the above students will influence their intelligibility and comprehensibility assessments. Thus, due to the contact that these Japanese listeners have had with these accents, it is believed that they will find the Japanese speaker most understandable followed by the U.S., Taiwan, and India.

Statistically, significant differences were found among all of the speakers except between the American and Taiwanese. It appears that the conclusions reached by researchers Smith and Bisazza (1982) that exposure to one accent will lead to greater intelligibility does not necessarily cover all groups and types of EFL/ESL learners with regard to every speaker of English; their study involved Japanese ESL students living in Hawaii. While there is no doubt that these Japanese subjects were most familiar with the Japanese English accent, it is clear from the statistics that familiarity with the American accent was the second greatest among the four speakers. Furthermore, judging by the reported nationalities of English teachers which the subjects had had, it seems as though the subjects were even more familiar with Indian English than Taiwanese English. Yet, results show that 
the Indian speaker was found to be the least intelligible. Therefore, familiarity alone is not necessarily an accurate predictor of what English accent will be assessed as more intelligible.

Concerning the assessments by the subjects of comprehensibility, the results show that all four accents were found to be significantly different, thus supporting hypothesis 1 . The results also showed that after the Japanese speaker, the Taiwanese speaker was judged to be the most comprehensible, followed by the Indian and finally the American speaker. Again, as with intelligibility, it is clear that familiarity alone is only relevant with regard to the Japanese speaker. It is interesting to note that the order in which the speakers emerged for intelligibility and comprehensibility was different. This supports the claim for a need to break down any general term of intelligibility into the more specific components of intelligibility and comprehensibility when under research. However, why the least familiar Taiwanese English accent should be judged equally intelligible as the American accent, more intelligible than the Indian accent, and more comprehensible than both is somewhat of a puzzle.

At first look, the Chinese or the Taiwanese variety of Chinese is completely different linguistically from Japanese. Therefore, any similarity of language background would not seem an adequate explanation of why the Japanese subjects found the Taiwanese speaker intelligible and comprehensible to the degree that they did. However, it was related to me by 
a Chinese instructor that the Chinese intonation patterns are different when Chinese is read. In Chinese, due to the unique writing system, words are given an equal amount of emphasis or stress when read. In addition, the transition from a tonal language like Chinese to a non-tonal language like English, could lead a Chinese speaker to pay particular attention to English pronunciation over emphasizing the enunciation of many words. In fact, in discussing the results of research with the Taiwanese speaker on the recording, she related to me that indeed she often pays close attention to her English pronunciation due to the transfer from the tonal language of Chinese.

I am speculating that when reading the passage for the comprehensibility of the instrument, the words were read in such a manner that each word was equally emphasized in a distinct manner due to the transfer from Chinese as described above. It is probable that this intonation pattern resulting from Chinese speakers reading English more closely mimics that of a syllable-timed language like Japanese. Thus, it is highly likely that Japanese speakers could have found this Taiwanese variety of English more comprehensible than that of the Indian or American variety.

As noted before, assessment of intelligibility by the subjects seems to operate in a somewhat different manner than comprehensibility. The fact that the American variety fared much better on intelligibility probably has more to due with the nature of the instrument itself. The cloze test enabled the subjects to prepare themselves to concentrate on listening for two particular 
words per sentence. That is, the sentences with the two- word omissions were given to the subjects to read before hand. Therefore, comprehensibility of the whole sentence was not necessary to do well on the test. In addition, the cloze sentences were relatively short. Consequently, it is likely that subjects' familiarity with the American variety was, in fact, helpful. Single word pronunciation appears to be the important factor in performing well on the cloze test rather than intonation and stress patterns throughout an entire passage. Again, as with comprehensibility, the pronunciation strategy used by the Taiwanese speaker seems help these Japanese subjects find this variety of English intelligible.

This explanation seems to be pertinent to the subjects assessment of the Indian variety of English as well. Kachru (1983) claims that most Indian languages are syllable timed which is often transferred to English. This transfer would help explain the subjects' assessment of Indian English as more comprehensible than the American variety, as it would more closely approximate the intonation pattern of Japanese English. Japanese English is a variety resulting from a transfer from a syllable-time language as well. Furthermore, this might explain the subjects' assessing the Indian variety of English as least intelligible. Again, familiarity with single word pronunciation in English seems to be a factor in intelligibility.

Interestingly, it appears that the word 'familiarity' may be too vague a term as it is used in hypothesis 3 . Familiarity with a language might just 
simply mean exposure to a minority language within one's culture. Under this definition, for example, most Americans are very familiar with Spanish; however, this does not mean that most Americans find Spanish intelligible or comprehensible. Moreover, exposure or 'active' exposure as used by Smith and Bisazza (1982), may not accurately describe one's particular involvement with a language. In order to gain a more complete understanding of a language learner's familiarity or exposure to a particular language, specific details should be revealed. Details such as: How qualified were the instructors? How many years did the student spend studying the language? In what country did the instruction take place? In which four skill areas, (speaking, listening, reading and writing), did the student receive instruction? What was the nature of instruction for these skills, e.g., did a student receive pronunciation practice, and what were the number of hours per week spent on particular skills etc.? It is clear that saying an individual is familiar with or had exposure to a language does not necessarily provide a picture that might lead one to make specific predictions concerning, at least, intelligibility and comprehensibility.

\section{Correlation Results}

The correlation analysis for this study were based on the final hypothesis, 4. Again, for reference, this hypothesis is as follows: 
4. There is a positive relationship between student subjective assessment of speaker intelligibility and comprehensibility, and student achievement on comprehension and intelligibility tests based on the taped material.

Particularly for this research, the first two questions on the subjective evaluation questionnaire were each correlated with the results for both the intelligibility and comprehensibility assessments based on each of the four taped speakers. The two evaluative questions were:

1. Could you understand what the presenter said?

( ) ( ) ( ) ( )

easily with some difficulty with great difficulty not at all

2. How much of the recording did you understand?

$\begin{array}{lccccc}(\text { ) } & (\text { ( ) } & (\text { ) } & (\text { ) } & (\text { ) } & (\text { ) } \\ 90 \%>75 \%-89 \% & 61 \%-74 \% & 50 \%-60 \% & 34 \%-49 \% & <33 \%\end{array}$

The results indicated that the correlations were too weak to draw any conclusions. It would seem that this particular group of subjects were not able to correctly predict how well they had done on the intelligibility and comprehensibility tests. It is most likely a consequence of the subjects' English ability. Whether or not this is accurate might depend on different factors such as the particular scales used for the measurement. However, the responses to the questions might be related to the nature of Japanese culture and their aversion to making strong, definite statements. It might be that the subjects instinctively chose those answers toward the middle of the scale. Interestingly, these results are contrary to the findings from the research by Smith and Bisazza (1982). In fact, this study of Japanese university students 
demonstrates the specific nature of performance found among various language learner groups. It gives evidence for the need to conduct English intelligibility research using a variety of groups of subjects in a variety of situations. Initial generalizations should be specific to the group under investigation.

\section{Other Results from Subjective Evaluation Questionnaire}

The final three questions from the subjective evaluation questionnaire provided some interesting answers, if not clues, to possible explanations for the results. These remaining questions were:

3. Did you have difficulty understanding the recording?

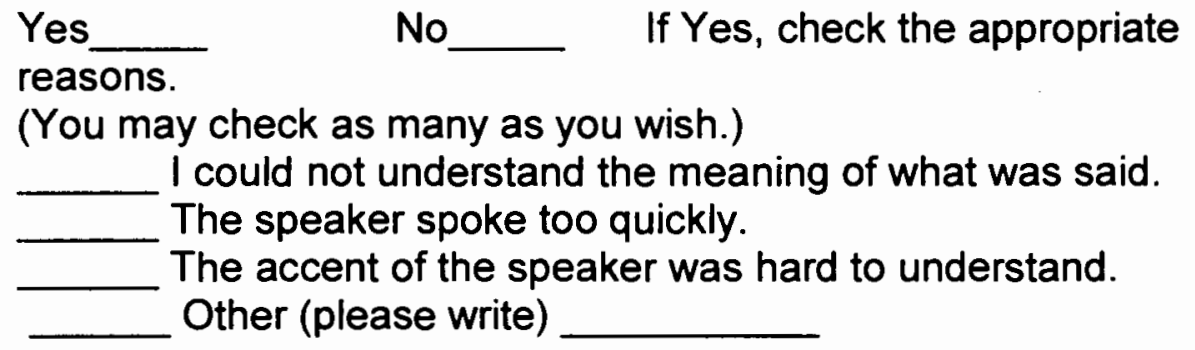

4. What was the speaker's nationality?

5. Based on what you heard, it seems that the speaker is (check as many as you wish):

Highly educated Educated Not well educated A native speaker A A non-native speaker A speaker of Standard English A speaker of non-Standard English

The results for question three revealed a few prominent percentages. First, regarding those answers based on the Japanese speaker, it is clearly apparent that a majority, almost $70 \%$, felt that they had no trouble 
understanding the recording. This particular question seems to counter the correlation results indicating low predictive achievement on an objective evaluative measure.

However, in judging the percentages based on the results from the Taiwanese, Indian and American speakers, the percentage of subjects claiming no difficulty was approximately 13,7 and 11 percent respectively. It appears that the subjects underestimated their performance on the tests, especially concerning the Taiwanese speaker. The results from this question parallels the correlation results showing low predictive ability. Although there may have been confusion due to the fact that question three did not delineate between the intelligibility and comprehensibility aspects, the question required subjects to give their overall evaluation.

To continue with the results from question three, the percentages from the reason about speed of speech were striking. While the actual speeds for the passages read by the Japanese, Taiwanese, Indian and American were $85,90,80$ and 80 seconds respectively, the percentages of those who reported, 'spoke too quickly', was approximately 10, 30, 50 and 70 percent, (in the same order as above). It is remarkable how these results mimic the pattern of the results obtained for the comprehensibility assessment. It would seem that perceived speed of speech accurately predicted achieverment on the comprehensibility test. However, I find it unlikely that these students could distinguish the difference of five or even ten seconds over a span of 80 to 90 
seconds. In fact, the actual speeds are different from what the percentages in question three would predict. It is my guess that intonation patterns, as described earlier in this discussion, affect the speech rate perceived by these subjects. In turn, this affected the comprehensibility assessments.

Finally, with respect to the results from question three, I wish to look at the category of, 'trouble with accent'. The results here showed, not surprisingly, that there was little perceived trouble with the Japanese accent; only 11 percent reported trouble. Thirty two percent reported having trouble with the American speaker, and the Taiwanese and Indian speaker were the same at 58 percent. These results appear to describe the amount of exposure the subjects had had to the particular varieties rather than actual difficulty. In other words, if the subjects did not recognize the speaker nationality, then this was perceived as difficulty with that accent.

This ability to recognize the speakers' nationalities was the focus of question four from the questionnaire. At first glance, it is clear that the subjects were only able to identify the Japanese and American speaker; approximately 80 percent correctly identified the Japanese speaker and approximately 60 percent correctly identified the American. These results are not surprising and support the fact that the subjects have had the most exposure to these two varieties; the subjects' instructor at the time this instrument was given was American. The choices of nationality for the other two speakers was literally all over the map, indicating pure guessing on the 
subjects' part. However, the predominate guess for both the Taiwanese and Indian speaker was American, both at 37 percent of the subjects. It almost seems as though the default answer when unsure was American. This might reveal a preoccupation with American English as the main target variety for EFL learners in Japan. The United Kingdom, and France, are the only other countries that had any significant number of guesses. It almost seems that to these Japanese subjects, foreigners who speak English are overwhelmingly likely to be Americans, then the British and French to some extent.

The last set of results to discuss came from the final question of the subjective evaluation questionnaire. This question asked the subjects to give their perceptions about the speaker's education level, whether or not the speaker was native or non-native, and whether the speaker used standard or non-standard English. The results to this question provided only a few indications about the subjects' certainty.

It was quite clear that the subjects were sure about whether or not the speakers from America and Japan were native speakers or not. $83 \%$ of subjects thought the Japanese speaker was a non-native speaker and $81 \%$ thought the American was a native speaker. Not only were these degrees of certainty almost identical, but these percentages reflect the subjects' ability to correctly guess the nationality for these two speakers. Therefore, it is likely that the subjects, having already decided on the nationalities of the American 
and Japanese speakers, simply extrapolated to the native/non-native delineation.

Continuing with question five, the guesses for the level of education show a trend toward the middle. However, there seems to be a slight shift in guesses towards 'highly educated/educated' for the American speaker. Although, the highest percentage for each speaker was within the 'safe' middle choice of 'educated'. Interestingly, I had expected a greater percentage of the subjects to choose 'highly educated' for the Japanese speaker. It seems that having identified the Japanese speaker, there was not any bias shown due to same nationality.

Finally for question five, the choices concerning 'standard English/nonstandard English' revealed that the subjects were rather unsure about to what they were listening. Although again, the percentage of subjects choosing 'standard English' for the American speaker was greatest among the four speakers. It is interesting to note that the one speaker that the subjects assessed to be least comprehensible would also be deemed the user of standard English. It seems as though these subjects believe that if they do not understand a variety of English, then it must be standard English, and vice versa. Most likely, the answer is that these subjects have been conditioned to believe that an Inner Circle variety of English is necessarily the standard form regardless of the speaker. 


\section{CONCLUSION}

First, it seems true that the phonological differences, 'accents', in educated speakers of English from Inner Circle, Outer Circle, and Expanding Circle countries as defined by Kachru (1985), (specifically the United States, India, Taiwan and Japan), affect the intelligibility and comprehensibility assessments of these speakers made by beginning Japanese EFL university students. However, regarding intelligibility, the American and Taiwanese speakers were found to be equally intelligible. Furthermore, assessments for intelligibility and comprehensibility were found to operate separately, therefore supporting the need to keep these terms distinct in research.

It was not surprising that the results of this study showed that the Japanese speaker of English was assessed by the Japanese subjects to be the most intelligible and comprehensible. While all of the subjects have been exposed to other varieties of English, (mostly Inner Circle varieties), the primary English teachers throughout most of the subjects' education have been Japanese. Furthermore, the subjects' English proficiency, the unique use of English loanwords in Japanese, the historical negligence of teaching English communicative skills, and the stress patterns of Japanese have all contributed to these beginning university students assessing the Japanese speaker as most intelligible and comprehensible. In fact, it seems as though 
the stress or intonation patterns seem to influence the subjects' assessments of comprehensibility more than familiarity.

In addition, the term familiarity, much like the general use of intelligibility, should be used carefully in research. Specific descriptions of what is meant by familiarity should be explained in describing, at least, a language learner's particular involvement with a language.

The correlation results in this study showed that the subjects were not able to subjectively evaluate their objective performance on the measures given. However, the results for question three of the subjective evaluation questionnaire did indicate that the subjects did exhibit some predictive achievement on an objective evaluative measure. The reported difficulty with speed seemed to predict the achievement on the comprehensibility test.

Finally, other results from the questionnaire indicated that at least exposure to a particular variety of English leads to accurate guesses as to nationality of speaker; the subjects were fairly successful at identifying the Japanese and American speakers. Moreover, these accurate guesses lead to accurate answers regarding native speakers and use of standard English.

\section{IMPLICATIONS FOR WORLD ENGLISHES AND TESOL}

As the huge number of English speakers across the globe continues to grow, it gives more evidence to the fact that English has become a world 
language used in a myriad of circumstances for many different purposes. As English is bent and changed to accommodate those cultures who have for one, reason or another, adopted the language, so too must the users of English around the world accommodate these changes if international communication is to take place. International intelligibility should be the goal for learners of English who decide that their purpose for using the language will be for communication across several cultures. Moreover, simply coming from an Inner Circle country does not necessarily guarantee intelligibility. In fact, in an international climate these Inner Circle English speakers will no longer be the sole judge of intelligibility, but will themselves be judge by other English speakers from Outer and Expanding Circle countries. With this stated, questions about what comprises international intelligibility in English arise.

I believe international intelligibility in English encompasses that English which is spoken by educated speakers across the many varieties. However, from this study, it is apparent that not all educated speakers of English are found, at least, to be equally intelligible and comprehensible to all English learners. Indeed, I picture international intelligibility not as one distinct dialect, but rather a loosely defined range where these educated varieties of English fall. To say that one is competent in English internationally, is to say that one can understand and be understood by speakers of the varieties within this range. 
Therefore, with regard to the subjects participating in this study, it would seem that these English learners are beginning to only understand a limited part of this internationally intelligible range. Depending on a particular learner's wants and needs, this English proficiency level may suffice. However, if these engineering students are to someday attend international conferences, for example, then it is apparent that these students need to improve their English proficiency to accommodate more varieties such as the American.

In particular, these Japanese English learners and their teachers should be made aware of the differences in stress or intonation patterns that exist in the different English varieties. Judging by the results of this research, it appears as though varieties from the Inner Circle pose a particular problem. I suggest that Japanese English learners need more active pronunciation lessons and practice. Apparently, simple exposure to the American variety of English, as is the case with these Japanese students, is not sufficient for acquisition of pronunciation rules. Furthermore, as was described in chapter two, the pervasiveness of English loanwords seems to provide significant interference in the acquisition of alternative English pronunciation. 


\section{LIMITATIONS AND METHODOLOGICAL PROBLEMS}

In order to include a large number of subjects for this study, different sentences and passages were used for the cloze and passage tests. Even though steps were taken to ensure the same level of difficulty for the passages, it might still be argued that one or more of the passages were more difficult than the others. Furthermore, the choices of content to quiz could have skewed the results as well.

In addition, due to the fact that only one person represented each English variety, differences in intelligibility and comprehensibility results could be attributed to the individual speaker instead of the variety itself. Given the size of the project, it was not feasible to include more than one representative. Furthermore, for the same reason, the results for each variety cannot be said to necessarily represent the broader Inner, Outer, and Expanding Circles of English variety grouping.

Moreover, it is not sure whether the scales used to measure correlation were accurate due to cultural influence regarding making strong statements. In addition, the tests themselves were short in order to alleviate boredom, but the length could have led to scores which were not entirely evaluative of subject performance. 
Finally, it should be noted that the speech being assessed within this study is somewhat artificial in nature. Due to the constraints of this particular research, true conversation samples would have been impractical.

\section{SUGGESTIONS FOR FURTHER RESEARCH}

If a follow up study were done to confirm trends and conclusions from this research, questions raised in the previous section might be addressed. For example, the passages and sentences read for the comprehensibility and intelligibility aspect should be kept the same for all speakers. This would require a much larger group of students for the results to be statistically valid, yet would assure complete equality in difficulty for the passage and cloze tests. In addition, I would make sure that the reading speed for the entire passage was identical. Moreover, an alternative scale should be devised in order to confirm the correlation results indicating that subjects were not able to subjectively evaluate their objective performance on the measures given. Also, the gender make up of the study should be varied in order to determine if this could be a factor influencing intelligibility and comprehensibility. Finally, more speakers representing each language as well as the Inner, Outer, and Expanding Circles should be used in order to give a more complete picture of intelligibility and comprehensibility. 
Concerning the assumptions that stress or intonation patterns play an important role in the assessments by Japanese English learners of intelligibility and comprehensibility, more research should be conducted to identify the particular problems. This research might include grouping different English varieties according to similar stress patterns and then identifying those groups with which Japanese learners are most likely to have difficulty. In addition, an investigation into which pronunciation teaching techniques would be effective for instruction of particular English varieties, or groups of varieties, might be taken as well. 


\section{REFERENCES}

Chiba, R., Matsuura, H., \& Yamamoto, A. (1995). Japanese attitudes toward English accents. World Englishes, 14, 77-86.

Crystal, D. (1985). How many millions? the statistics of English today. English Today, 1, 7-9.

Giddens, G. Davis, Miles \& Getz, Stan. (1995). In The World Book Encyclopedia.

Ike, M. (1995). A historical review of English in Japan. World Englishes, 14, 3-11.

Kachru, B. (1983). The Indianization of English: The English language in India. Delhi: Oxford University Press.

Kachru, B. (1985). Standards, codification, and sociolinguistic realism: the English language in the outer circle. In Quirk and Widdowson (Eds.), English in the world: teaching and learning the languages and literatures (pp.11-30). Cambridge: Cambridge University Press.

Kachru, B. (1990). World Englishes and applied linguistics. World Englishes, 9(1), 3-20

Kachru, B. (1992). World Englishes: approaches, issues and resources. Language Teaching, Jan., 1-14.

Kachru, B. (1992). Models for non-native Englishes. In Kachru, Braj B. (Ed), The other tongue (pp. 48-74). Urbana: University of Illinois Press.

Kachru, B. (1995). Teaching world Englishes without myths. In Gill, S. K. et. al. (Eds.), International English language education conference, national and international challenges and responses (pp. 1-19). Bangi: Pusat Bahasa Universiti Kebangsaan.

Kachru, B. (1996). World Englishes: Agony and ecstasy. Journal of Aesthetic Education, 20 (2), 135-155. 
Koike, I., et al.(1990). Integrated report of teaching English in Japanese schools: retrospects and prospects. Tokyo: Keio University Press.

Koike, I., \& Tanaka, H. (1995). English in foreign language education policy in Japan: toward the twenty-first century. World Englishes, 14, 13-25.

Nelson, C.L. (1988). Perspectives on world English. Contemporary Education, $\underline{59(2)}, 86-90$.

Nelson, C.L. (1992). My language, your culture: whose communicative competence. In Kachru, Braj B. (Ed), The other tongue (pp. 327-339). Urbana: University of Illinois Press.

Nelson, C.L. (1995). Intelligibility and world Englishes in the classroom. World Englishes, 14, 273-279.

Norusis, M. J. (1993). SPSS for Windows base system user's quide release 6.0. Chicago: SPSS Inc..

Nunan, D. (1992). Research methods in language learning. New York: Cambridge University Press.

Platt, J., \& Weber, H. (1979). English in Singapore and Malaysia: status, features, functions. Kuala Lumpur: Oxford University Press.

Smith, L.E., \& Rafiqzad (1979). English for cross-cultural communication: the question of intelligibility. TESOL Quarterly, 13, 371-380.

Smith, L.E., \& Bisazza, J.A. (1982). The comprehensibility of three varieties of English for college students in seven countries. Language Learning, 32, 259-270.

Smith, L.E. (1983). Some distinctive features of EIIL vs. ESOL in English language education. In Smith, L.E. (Ed.), Readings in English as an international language (pp.13-20). New York: Pergamon Press.

Smith, L.E., \& Nelson, C.L. (1985). International intelligibility of English: directions and resources. World Englishes, 4, 333-342.

Smith, L.E. (1992). Spread of English and issues of intelligibility. In Kachru, Braj B. (Ed), The other tongue (pp. 75-90). Urbana: University of Illinois Press. 
Stanlaw, J. (1992). English in Japanese communicative strategies. In Kachru, Braj B. (Ed), The other tongue (178-208). Urbana: University of Illinois Press.

Strevens, P. (1992). English as an international language: directions in the 1990s. In Kachru, Braj B. (Ed), The other tongue (pp. 27-47). Urbana: University of Illinois Press.

Tanaka, S. O. (1995). The Japanese media and English. World Englishes, 14, 37-53.

Tirro, F. Marsalis, Wynton \& Coltrane, John. (1995). In The World Book Encyclopedia.

Wynn, R., \& Boise, M. Coltrane, John. In R. Wynn (Ed.), All music guide to jazz (p. 166). San Francisco: Miller Freeman Books. 
APPENDIX A

PASSAGES AND CLOZE TESTS 


\section{PASSAGE AND CLOZE TESTS FOR JAPANESE SPEAKER}

Ella Fitzgerald is among the greatest singers in jazz history. She is known for her beautiful tone and perfect intonation. Fitzgerald also has a powerful sense of jazz feeling. She also became famous for her ability in scat singing.

Fitzgerald was born in Newport News, Virginia. Her father died when she was a child. She then moved to New York with her mother. In 1935, Ella Fitzgerald won a singing contest at the famous Apollo Theater in Harlem. Because she won the contest, she began to sing with the famous, big band drummer Chick Webb. Fitzgerald later became the band's leading singer. She recorded her first big song, "A-Tisket, A-Tasket," with the band in 1938.

When Chick Webb, the band leader died, Fitzgerald became the leader the band. She led the band until 1942. In 1942 she began a career as a solo singer, and she sang with other vocal groups. Fitzgerald became more famous working with the "Jazz at the Philharmonic," touring group beginning in 1948.

1. For what did Ella Fitzgerald become famous?

a. Her ability to play the saxophone.

b. Her ability in scat singing.

c. Her ability to sing ballads.

2. When did Fitzgerald win a singing contest at the Apollo Theater?
a. 1945.
b. 1955.
c. 1935 .

3. In which band did Fitzgerald first sing?

a. Duke Ellington's Band.

b. Chick Webb's Band.

c. Count Basie's Band.

4. Where was Fitzgerald born?

a. Newport News, Virginia.

b. New York City.

c. Saint Louis. 
5. What was Fitzgerald's first big song?

a. "She Didn't Say Yes".

b. "Undecided".

c. "A-Tisket A-Tasket".

Cloze test: (underlined words were omitted)

1. Ella Fitzgerald has an amazing ability to swing.

2. Ella Fitzgerald had very successful albums with Louis Armstrong.

3. Fitzgerald issued recordings in both jazz and pop. 


\section{PASSAGE AND CLOZE TESTS FOR TAIWANESE SPEAKER}

Miles Davis was one of the most influential American jazz trumpeters and bandleaders in jazz history. He became famous for a forceful but lyrical trumpet style. His moody tone and original ideas made him one of the most imitated musicians of his day.

Miles Dewey Davis III was born in Alton, III in 1926. In 1945, he went to New York City to study music at the Julliard School. However, he spent most of his time performing with jazz bands. Davis often play in a quintet led by alto saxophonist Charlie Parker. That group helped create bebop. This style is a complicated, modern form of jazz. In 1949 and 1950, Davis led a nine-piece band in several recordings. This band helped develop cool jazz. Cool Jazz is a style that has rich colors and emotional restraint.

In the late sixties, Davis helped develop fusion. Fusion was a movement that combined parts of rock music with jazz. Miles Davis died in 1991.

1. What type of trumpet style did Miles Davis have?
a. Mellow.
b. Relaxed.
c. Forceful.

2. What saxophonist did Davis often play with?
a. Ornette Coleman.
b. Lester Young
c. Charlie Parker

3. What style of jazz did Davis's nine-piece band help develop?
a. Cool.
b. Swing.
c. Free.

4. Where did Miles Davis study music in 1945 ?
a. Chicago.
b. New York.
c. Los Angeles. 
5. When did Miles Davis die?
a. 1991.
b. 1989.
c. 1990 .

Cloze test: (underlined words were omitted)

1. Miles Davis kept changing his style during his career.

2. One famous album by Davis was relaxin'.

3. In 1969 , Davis took his music in a new direction with "In a Silent Way". 


\section{PASSAGE AND CLOZE TESTS FOR INDIAN SPEAKER}

John Coltrane was a jazz saxophonist and composer. Coltrane had a unique style that made him much debated. He was one of the most famous jazz musicians of the 60's. Some of his best known works are 'Giant Steps' and 'Blue Train.'

Coltrane was born in Hamlet, North Carolina in 1926. He played in the bands of Dizzy Gillespie and Johnny Hodges during the 1950's. He became famous as a soloist with the Miles Davis Quintet. Coltrane formed his own quartet in 1960. He then recorded the popular song 'My Favorite Things.'

By the mid 1960's, John Coltrane made changes to his group. He included his wife, Alice, as the pianist. In the late 60's Coltrane's music was influenced by his interest in Asian music. This included the music of India. John Coltrane became famous playing the tenor sax. However, Coltrane also played the soprano sax starting in 1960. He made the soprano sax popular among jazz musicians. Coltrane died in 1967.

1. John Coltrane was a saxophonist and
a. trumpeter.
b. composer.
c. singer.

2. What was one of his best known works?
a. "Blue Train".
b. "Caravan".
c. "Take the A-Train".

3. When did Coltrane form his own quartet?
a. 1959
b. 1960
c. 1961

4. What country's music influenced John Coltrane?
a. Morocco.
b. Spain.
c. India. 
5. What saxophone did Coltrane make popular?

a. Soprano.

b. Alto.

c. Baritone.

Cloze test: (underlined words were omitted)

1. John Coltrane spent time in the military in Hawaii.

2. John Coltrane recorded first with Gillespie in 1949.

3. Coltrane won several Down Beat polls in the 1960's. 


\section{PASSAGE AND CLOZE TESTS FOR AMERICAN SPEAKER}

Wynton Marsalis is an American trumpeter. He is famous as both a jazz and a classical musician. Since the early 1980's, Marsalis has been one of the most important people in jazz. His style is based on jazz history. He is also known for his great technique. Marsalis is a very good speaker. He visits schools to talk about jazz to young people. In 1991, Marsalis became the artistic director of the Lincoln Center jazz program in New York City.

Marsalis was born in New Orleans in 1961. He studied jazz and classical music with many teachers. One of his teachers was his father, Ellis Marsalis, a respected pianist. At age 14, Marsalis performed with the New Orleans Symphony. Marsalis made his first recordings with Art Blakey's group in 1980. In 1982, he led a band with his brother, Branford Marsalis, a sax player. Since then, Marsalis has performed with his own small groups. Sometimes he records with his father and brother.

1. Since when has Wynton Marsalis been influential in Jazz?
A. Since the early 1960's.
B. Since the early 1970's.
C. Since the early 1980's.

2. Where was Wynton Marsalis born?
A. New Orleans.
B. Chicago.
C. New York.

3. What instrument does Wynton Marsalis play?
A. Saxophone.
B. Trumpet.
C. Drums.

4. Where is Marsalis the artistic director?
A. New Orleans Symphony.
B. Lincoln Center Jazz Program.
C. The Jazz Messengers. 
5. Who is Wynton Marsalis's brother?
A. Branford.
B. Charlie.
C. Sonny.

Cloze test: (underlined words were omitted)

1. One of Wynton Marsalis's best known recordings is Live at Blues Alley.

2. Wynton Marsalis was given his first trumpet at age six by the famous Al Hirt.

3. Wynton Marsalis is concerned with the preservation of jazz. 


\section{SAMPLE PASSAGE AND CLOZE TESTS}

Stan Getz was an American jazz tenor saxophonist known for his light, smooth tone and lyrical approach to improvisation. Getz rose to fame in the late 1940's, playing a style known as cool jazz. In the early 1960's, he helped to popularize the style called bossa nova. This style blends the music of Brazilian sambas with the improvisations and harmonies of American jazz.

Stan Getz was born in Philadelphia. He began his career with the Teagarden band in 1943. He earned recognition with Woody Herman's band from 1947 to 1949. He recorded his first famous solo "Early Autumn" with Herman's band in 1948. Getz formed a quartet in 1949. He made his first bossa nova recording in 1962. Getz continued to lead a successful combo during the 1970's and 1980's. Getz died in 1991.

1. What nationality was Stan Getz?
a. American.
b. Canadian.
c. German.

2. What style did Getz popularize?
a. Latin.
b. Bossa nova.
c. Cool.

3. Where does bossa nova come from?
a. Brazil.
b. Mexico.
c. Cuba.

4. What was Getz's first famous solo?
a. "Round Midnight".
b. "Lemon Drop".
c. "Early Autumn".

5. When did Getz die?
a. 1990 .
b. 1991 .
c. 1992 . 
Cloze test: (underlined words were omitted)

1. Getz recorded frequently for Verve.

2. Getz was perhaps the cool school's most popular player.

3. Getz won Grammy awards in 1962 and 1964. 
APPENDIX B

SUBJECTIVE AND PERSONAL DATA QUESTIONNAIRES 


\section{PERSONAL DATA QUESTIONNAIRE}

1. How many years have you studied English?

2. Have you ever taken private English lessons? No Yes How many years? Language school Cram school Private Instructor

3. Have you ever studied English abroad? Yes

No

If yes, how long?

4. What is your age?

5. Have you ever had foreign English instructors? Yes No If yes, how many? What nationalities?

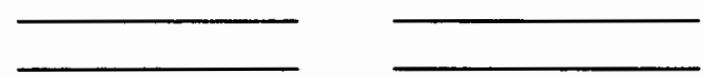

6. I am female male

7. Have you ever taken the TOFEL test? No Yes Score 


\section{SUBJECTIVE ASSESSMENT QUESTIONNAIRE}

Directions: Please answer the following questions by putting a check mark ( ) in the appropriate space provided, according to how you feel about the taped material that you have just heard.

1. Could you understand what the presenter said?
( )
( )
( )
( )

easily with some difficulty with great difficulty not at all

2. How much of the recording did you understand?

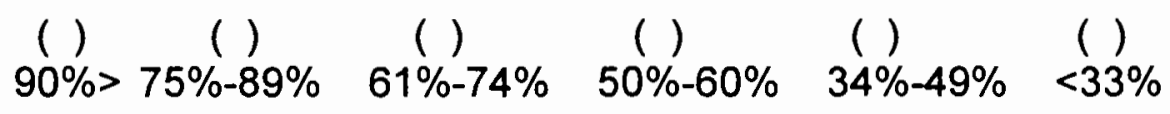

3. Did you have difficulty understanding the recording?

Yes__ No___ If Yes, check the appropriate reasons.

(You may check as many as you wish.)

I could not understand the meaning of what was said.

The speaker spoke too quickly.

The accent of the speaker was hard to understand.

Other (please write)

4. What was the speaker's nationality? 
5. Based on what you heard, it seems that the speaker is (check as many as you wish):

Highly educated Educated Not well educated

A native speaker A non-native speaker

A speaker of Standard English

A speaker of non-Standard English 
APPENDIX C

TRANSLATIONS AND BACK-TRANSLATIONS 


\section{Cover Paper/Consent Form}

表紙（同意書）

\section{異なった英語のアクセントに対する日本人の理解力の評着}

この研究は、話し手の英語のアクセントによる大学生の理解についての知識を深めるこ とを目的としています。

この研究へのあなたの参加は自由意志によるもので、参加するかしないかの決定があな たの成續に影響を与えることはありません。この研究では，あなたの名前を記入しないこ と、又確哂番号等が使われていないことによって、完全な匿名が保证されています。あな たの担当教䀦は、この研究についてのあなたの筫問に答えてくれます。

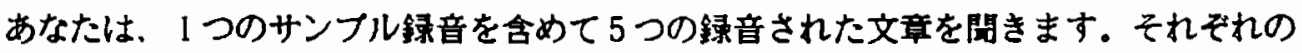

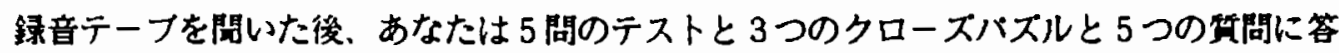

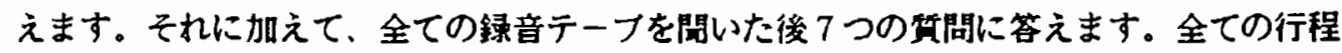
は.約 30 分かかります。

この研究の参加に同意した場合、次のページに進み、テスト、問に答えてください。 この研究への参加はあなたの成綪に影帮を与えませんが、最善の努力をして筫問に答えて くだい。あなたの基加に感时をすると共に、この研究の結果によって、あなたのような 学生に对する英語教育が改善される方に進めることができれはと願っています。

この研究は、David Levinの修士論文のI部として実施され、ボートランド州立大学の Office of Research and Sponsored Projects によって承絜されています。この研究に ついて意見、感想等がある場合は、David Levin (3329 S.E. 7th, Portland, OR 97202 USA, Tel. 503-236-9763 又はHuman Subjects Research Review Committee OfficeのArezau Movahed (Portland State University, Portland, OR 97207 USA, Tel. 503-725-3418)までご連格ください。 


\section{Cover Paper/Consent Form (Back-translation)}

Cover Paper (Agreement)

Japanese Comprehension Evaluations of Different English Accents

The purpose of this research is to promote an understanding of how difficult it is to comprehend some types of English speakers for university students like yourself.

It is your choice whether or not to participate in this research. Whether you participate or not will not affect your grade. Your perfect anonymity in this research is guaranteed by not using your name or identification number. Your teacher will answer your questions about this research.

You will listen to five recordings including one sample recording. After you listen to each recording, you will answer the test consisting of five questions, three cloze tests, and then answer five questions about the speaker. In addition, you will answer seven questions after listening to all the recordings. It will take about thirty minutes to complete everything.

By answering the test and the questions, I understand you agree to participate in this research. (If you agree to participate in this research, go on to the next page, and answer the test and questions.) This research does not affect your grade, but please do your best. 
I appreciate your participation and hope to improve English education for students like yourself by the results of this research.

This research is conducted as a part of David Levin's thesis, and approved by the Office of Research and Sponsored Projects in Portland State University. If you have any opinions or concerns about this research, please contact David Levin (3329 SE 7th, Portland, OR 97202 USA, Tel 503-2369753 or Arezau Movahed from Human Subjects Research Review Committee Office Portland State University, Portland, OR 97207 USA 503-725-3418). 
Subjective Questionnaire

説明：あなたが今閏いたテーフについてどのように感したかに従って，以下の買問に答 えてください。

1 あなたは、話者の言ったことを理解できましたか？

筬単であった 少し難しかった 大变難しかった

$\left(\begin{array}{llll}1 & (1) & (1)\end{array}\right.$

2 あなたはテーブをどの程度理啁しましたか？
$90 \%>$
$75-89 \%$
$61-74 \%$
$50-60 \%$
$34-49 \%<33 \%$
$(1)$
(
(

3 あなたはテーフを理解することか難しかったですか？

はい いいえ

にはい」の場合は、道切だと思われる理由を選んでください。

(いくつ選んでもかまいません)

話の内容がからなかった。

話者の話すスヒーードが早すきた。

話者のアクセントが理解しにくかった。

その他 (理由を書いてください)

4 話者の国籍は何でし上う？

5 あなたが䦩いた感しでは、話者は，，。のうである。

(いくつ選んでもかまいません)

高学歷者である

英珸が舟国涪である

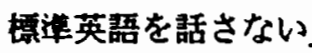

学歴がある 英吾が国鬥でない
あまり学歴がない

標望英語を話す 
Subjective Questionnaire (Back-translation)

Explanation: Please answer the following questions based on how you felt about the tape you listened to.

1. Did you understand what the speaker said?

Easy A little difficult Very difficult incomprehensible

2. How much did you understand the tape?

$90 \%>\quad 75-89 \% \quad 61-74 \% \quad 50-60 \% \quad 34-49 \% \ldots .<34 \%$

3. Was it difficult for you to understand the tape?

Yes No If you answered "yes", please choose the reasons. (You can choose as many as you want.)

I didn't understand what was said.

The speaker talked too fast.

I had a hard time understanding the speaker's accent.

Other (Please write the reasons.)

4. Where do you think the speaker is from?

5. What do you feel about the speaker based on what you heard? (You can choose as many as you want.)

Very educated Educated Not educated

Native English speaker Non-native English speaker

Standard English speaker Non-standard English speaker 
Personal Data Questionnaire

\section{PART 2}

1 あなたは英語を网年間勉強していますか？

2 英語のクラスを学外で受䜖したことがありますか？いいえはい 「はい」の場合. 何年間? 学習慗——英会話学校——家庭教師

3 海外で英語を勉強したことがありますか？いいえはい 「はい」の場合、その期間を書いてください

4 あなたは何蔵ですか？

5 あなたは今までに外人教師から英珸を習ったことがありますか？はいいいえ 「はい」の場合、何人から習いましたか？

その教師はどこの国の人ですか?

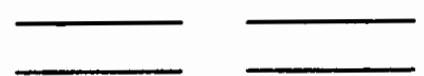

6 あなたの性別は 女性＼cjkstart男性

7 あなたはTOEFLテストを受矮したことがありますか？いいえはい 「はい」の場合、スコア 


\section{Personal Data Questionnaire (Back-translation)}

1. How long have you been studying English?

2. Have you ever taken English classes outside of school?

No Yes If you answered "yes", for how long and where?

A cram school An English conversation school A private teacher

3. Have you ever studied English abroad?

If you answered "yes", for how long?

4. How old are you?

5. Have you ever learned English from foreign teachers?

Yes No If you answered "yes", how many different teachers did you learn from? Where were the teachers from?

6. Your sex is Female Male

7. Have you ever taken the TOFEL test?

If you answered "yes", what was your score? 


\section{Passage Tests}

\section{Sample recording}

サンフル睩音

1. What nationality was Stan Getz?

(スタン ゲッツはどこの国の人でしたか?）

a. American アメリカ人

b. Canadian カ十夕人

c. German トイツ人

2. What style did Getz popularize?

(ゲッツはどのスタイルで有名でしたか？)

a. Latin ラテン

b. Bossa nova ボサノハ

c. Cool クール

3. Where does Bossa nova come from? (ボサノハはどこの国から伝わってきましたか?）

a. Brazil フララシル

b. Mexico メキシコ

c. Cuba キューバ

4. What was Getz's first famous solo? (ゲッツが最初に有名になったンロは何でしたか？)

a. "Round Mldnight" 「ラウンド ミッドナイト」

b. "Lemon Drop" 「レモン ドロッフ」

c. "Early Autumn" 「アーリー オータム」

5. When did Getz die?

(ゲッツはいつしくなりましたか?)
a. 1990 年
b. 1991 年
c. 1992 年 


\section{Recording 1}

\section{绿音 1}

1. For what did Ella Fitzgerald become famous?

(エラ フィッツジェラルドは何で有名になりましたか？)

a. Her ability to play the saxophone. サックスフォーンを焯くこと

b. Her ability in scat singing. スキャットを歌うこと

c. Her ability to sing ballads. バラードを歌うこと

2. When did Fitzgerald win a singing contest at the Apollo Theater?

(フィッッジェラルドは いつアボロ剧場で 歌のコンテストに勝ちましたか？)
a. 1945 年
b. 1955 年
c. 1935 年

3. In which band did Fitzgerald first sing?

(フィッツジェラルドは最初どのハンドで冸っていましたか?）
a. Duke Ellington's band. テューク エリントンのバント
b. Chick Webb's band. チック ウェップバンド
c. Count Basie's band. カウント ベイジーのハンド

4. Where was Fitzgerald born?

(フィッツジェラルドはどこで生まれましたか？)
a. Newport News, Virginia パージニア州 ニューボートニュース
b. New York ニューヨーク市
c. Saint Louis セントルイス

5. What was Fitzgerald's first big song?

(フィッツジェラルドの最初のヒット曲は何でしたか？)
a. "She Didn't Say Yes"「シー ティドンットセイ イエス」
b. "Undecided" 「アンティサイティッド
c. "A-Tisket A-Tasket" 「ア テスケット ア タスケット」 


\section{$\underline{\text { Recording } 2}$}

\section{绿音 2}

1. What type of trumpet style did Miles Davis have?

(マイルス テービスは、どの種類のトランペットスタイルでしたか？)
a. Mellow $メ \square-$
b. Relaxed リラックスト
c. Forceful フォースフル

2. What saxophonist did Davis often play with?

(デービスは.どのサックスフォーン フレーヤーとよく演奏しましたか？)
a. Ornette Coleman オーネット コールマン
b. Lester Young レスター ヤンダ
c. Charlie Parker チャーリーバーカー

3. What style of jazz did Davis's nine-piece band help develop? (テービスの 9 人制バンドは.どのジャススタイルの発達に役立ちましたか？)
a. Cool クール
b. Swing スインタ
c. Free フリー

4. Where did Miles Davis study music in 1945 ?

(1995 年にマイルス テービスはどこで音楽を勉強しましたか？)
a. Chicago シカコ
b. New York ニューヨーク
c. Los Angeles ロサンジェルス

5. When did Miles Davis die?

(マイルス デービスはいつ亡くなりましたか？)
a. 1991 年
b. 1989 年
c. 1990 年 


\section{Recording 3}

\section{録音 3}

1. John Coltrane was a saxophonist and

(ジョン コルトレインはサックスフォーン奏者で でした。
a. Trumpeter トランペット奏者
b. Composer 作曲家
c. Singer 歌手

2. What was one of Coltrane's best known works? (コルトレインの最もよく知られた曲の1つは何ですか?）
a. "Blue Train" 「フルートレイン」
b. "Caravan"「キャラバン」
c. "Take the A-Train" 「ティク ザ エー トレイン」

3. When did Coltrane form his own quartet? (コルトレインはいつ自分のカルテットを作りましたか？)
a. 1959 年
b. 1960 年
c. 1961 年

4. What country's music influenced John Coltrane? (どの国の音楽がション コルトレインに影響を与えましたか？)
a. Morocco モロッコ
b. Spain スペイン
c. India インド

5. What saxophone did Coltrane make popular? (どのサックスフォーンがコルトレインを有名にしましたか？)
a. Soprano ソブラノ
b. Alto アルト
c. Baritone バリトン 


\section{Recording 4}

粶音 4

1. Since when has Wynton Marsalis been influential in Jazz?

(いつからウイントン マルセラスはジャスに影響を与えていますか?)

a. Since the early 1960's. 1960 年初期的

b. Since the early 1970's. 1970 年初期加

c. Since the early 1980's. 1980 年初期加

2. Where was Wynton Marsalis born?

(ウイントン マルセラスはどこで生まれましたか?)

a. New Orieans ニューオリンズ

b. Chicago シカコ

c. New York $ニ ュ-ヨ-ク$

3. What instrument does Wynton Marsalis play? (ウイントン マルセラスはどの楽器を演奏しますか？)
a. Saxophone サックスフォーン
b. Trumpet トランペット
c. Drums トラムム

4. Where is Marsalis the artistic director? (ウイントン マルセラスはどこの芸術の演出家ですか?）

a. New Orieans Symphony ニューオリンス シンフォニー

b. Lincoln Center Jazz Program リンカーンセンター ジャス フロダラム

c. The Jazz Messengers ザジャス メッセンジャース

5. Who is Wynton Marsalis's brother? (ウイントン マルセラスの兄弟は雒ですか?)

a. Branford プランフォート

b. Charlie チャーリー

c. Sonny $+=-$ 